\title{
Die ontmaskering van die bose: Eksegetiese perspektiewe op geweld in Openbaring 18
}

\author{
Pieter G R de Villiers \\ Fakulteit Teologie \\ Universiteit van die Vrystaat
}

\begin{abstract}
Exposure of evil: Exegetical perspectives on violence in Revelation 18

This article investigates violence in Revelation 18 from an exegetical perspective because of its prominent role in contemporary debate on violence in the New Testament. It first discusses the complex meaning of violence in the light of the intricate composition of the book as a whole and this chapter in particular. It argues that, in contrast to what is often said in contemporary research about the incoherence of this passage, Revelation 18 is in fact a carefully composed ring composition in which the constitutive elements determine its meaning decisively and in which violence is a seminal motif. It also discusses how the rest of the text confirms the author's literary skills and the neat composition of Revelation 18 as a text about a violent city. The article then shows how the different elements in the text ironically delineate the downfall of the violent city of Babylon and the reasons for it. It sketches how the consequences of Babylon's fall are developed from an earthly and divine perspective. In all these different parts the prevalence of violence is spelled out.
\end{abstract}

\section{INLEIDING}

In die bespreking van geweld in die Nuwe Testament ${ }^{1}$ word Openbaring 18 soms deur navorsers as 'n spesiale voorbeeld gebruik. ${ }^{2}$ In die meeste gevalle

\footnotetext{
${ }^{1}$ Vir 'n definisie van geweld, kyk hier onder verder. Hierdie bundel wat die uitkoms is van 'n byeenkoms oor Geweld en die Nuwe Testament in Stellenbosch, 21-23 Januarie 2008, reflekteer die groeiende debat oor geweld en die Bybel.

${ }^{2}$ Yarbro Collins (1983) bied tans nog die beste agtergrond vir 'n besinning oor geweld in Openbaring 18. Haar teksanalise is 'n voorbeeld van eksegetiese werk wat die groter geheel uitspel, maar wat in die proses deurslaggewende materiaal op mikro-vlak nie in berekening bring nie.
} 


\section{Die ontmaskering van die bose}

word sekere gedeeltes (bv Op 18:4-8) uit die hoofstuk uitgelig en dan gebruik om verreikende uitsprake oor Openbaring se gewelddadige karakter te maak. Juis omdat Openbaring 'n komplekse, fyn verweefde teks is, kan sulke uitsprake die teks verwring of belangrike perspektiewe buite rekening laat. Openbaring 18 is naamlik 'n ringskomposisie waarin die verskillende elemente mekaar wesenlik bepaal. Hierdie insig in sy komplekse samestelling is juis ook van belang in die lig van 'n lank gevestigde neiging in die navorsing om die teks, en trouens groot dele van Openbaring as boek, se literêre aard en koherensie te bevraagteken of met agterdog te bejeën. ${ }^{3}$

Hierdie artikel wil vanuit eksegetiese hoek ${ }^{4}$ 'n bydrae maak tot die debat oor geweld in Openbaring 18 in besonder, maar daardeur ook in die boek as geheel. Maar dit wil, in kontras tot huidige lesings van geweld in die gedeelte, die teks as geheel ontleed met inagneming van eksegetiese materiaal op mikro-vlak ${ }^{5}$ en in die lig van die literêre karakter van die teks. ${ }^{6}$ Die uitsprake oor geweld in hierdie hoofstuk, hulle onderlinge verband en hulle funksie in die boek as geheel sal bespreek word om 'n eklektiese benadering tot die tema van geweld te verhinder en om 'n eksegetiese verantwoorde basis vir uitsprake oor geweld te voorsien. Die bydrae sal uitspel hoe die eksegetiese materiaal, meer as wat tot dusver aangedui is, die gewelddadige aard, oorsake en gevolge van die stad se val uitbeeld. Spesiale aandag word gegee aan die wyse waarop die komposisie van die hoofstuk die gehoor tot 'n transformatiewe respons wil lei deur óf vanuit 'n aardse óf hemelse perspektief na die gewelddadige stad se val te kyk. Ten slotte sal opmerkings oor die opdrag tot distansiëring en veral aan die problematiese weerwraak van gelowiges op die stad in Openbaring 18:4-8 gemaak word.

\footnotetext{
${ }^{3}$ Die mees berugte voorbeeld is die kommentaar van Charles (1920) wat oral in die boek bronne uitgewys het en chaotiese tekstoestande wou gevind het.

${ }^{4}$ In 'n tweede artikel, wat aan die einde van die onderhawige versameling van artikels oor geweld in HTS 64/4 (2008) verskyn, word die hermeneutiese implikasies van die eksegetiese materiaal in meer detail uitgewerk.

${ }^{5}$ Hiermee word onder andere bedoel, soos later ook duidelik sal word, dat die teks tot op sy individuele woorde ryk aan betekenis kan wees weens hulle verweefdheid in konfigurasies van soortgelyke woorde en motiewe, asook hulle intertekstuele karakter (bv in hulle aanspelinge op profetiese tradisies). Saam met die wyse waarop die woorde vroegChristelike oortuiginge wil uitbeeld en suggereer, beteken dit dat die teks 'n ryke tapisserie vorm waarin woorde en frases wêrelde van betekenis kan oproep. Die evokatiewe, poëtiese karakter van Openbaring is een van die groot redes vir die uiteenlopende en ryk resepsie daarvan.

${ }^{6}$ Die literêre benadering is, soos hieronder sal blyk, 'n benadering wat sal poog om die orale karakter van die boek, so wyd bespreek in navorsing oor Openbaring, in 'n groter raamwerk te plaas.
} 


\section{JOHANNES SE LITERÊRE BEDREWENHEID}

Dat Openbaring bedoel is om ook mondeling voorgedra te word, ${ }^{7}$ het soms tot gevolg dat die teks as ongesofistikeerd gereken word asof dit nie altyd netjies en samehangend gekomponeer is nie. So 'n siening bevraagteken die literêre karakter van Openbaring en oorweeg nie dat of hoe die teks wel deur'n skryfkultuur gevorm is nie. ${ }^{8}$ Die skryfkultuur blyk byvoorbeeld reeds uit die eenvoudige opmerking dat Johannes sy teks voorgelees wou gehad het (Op 1:3). Daar is egter heelwat ander inligting in die teks wat daarop wys dat Johannes besondere literêre vermoëns gehad het. Sy literêre bedrewenheid staan nie in spanning met die mondelinge karakter van die teks nie. Johannes wil juis deur sy literêre vermoëns sy teks optimaal inrig om mondeling effektief te kommunikeer. ${ }^{9}$ Wanneer hierdie vermoëns ontleed word, gee hulle in die geval van Openbaring $18^{10} \mathrm{n}$ besondere insig in sy verstaan van geweld.

\section{$2.1 \quad$ Komposisie}

Reeds 'n vlugtige lees van Openbaring onthul die skrywer se pogings om helder te kommunikeer. Hy deel byvoorbeeld sy teks in duidelike eenhede van vyf septette op (briewe, seëls, trompette, engele en bakke) wat spiraalagtige dieselfde inhoude herhaal en deur byvoeging van nuwe momente intensiewer

\footnotetext{
${ }^{7}$ Die sleutelverse in dié verband is Op 1:3 en 22:18, maar kyk ook die slot van elkeen van die sewe briewe met die oproep dat wie 'n oor het, moet hoor wat die Gees sê (Op 2:7, 11, 17, 29; 3:1, 13, 22). Barr (1986), Bauckham (1993:1-37) en Callahan (1995:459-60) het die struktuur van Openbaring as mondelinge voordrag bespreek. Vergelyk verder ook Soeting (1991) met sy fokus op Openbaring se musikale simboliek wat volgens hom die Joodse erediens reflekteer.
}

${ }^{8}$ Kommentare wat Johannes se skryfkuns hoog aanslaan is die vernuwende werk van Giblin (1991), maar ook reeds 'n onderskatte kommentaar soos dié van Kiddle (1946 [1940]). Giblin (1991:7) praat van Openbaring se "carefully-wrought literary structure" en Kiddle (1946:xxviixxix) prys die skrywer vir sy "creative genius," sy "skilful, and even subtle combination of visions" (t s v "what seems to be an awkward grafting of previously separate sources), van sy "high degree of skill in the intricate and yet clearly defined narration of his successive visions," terwyl sy boodskap aangebied word met "consistent deftness and accuracy. Moreover, the book as a whole has about it that impression of finish and confidence which marks the work of one who is master of his material. Not only do certain passages reach loftiness of expression which ranks them among the greatest literary achievements; there is a sustained grandeur and a successful endeavour to retain the reader's interest from the first verse to the last." Bauckham (1993:1-37) is by uitstek die kontemporêre kommentator wat Op se literêre vermoëns die beste en omvattendste gedokumenteer het.

\footnotetext{
${ }^{9}$ Maier (2002:91-122) skryf uitgebreid oor die mondelinge karakter van Openbaring, met verwysing na die baanbrekende werk van Barr en Ong. Dat die situasie kompleks is, blyk uit sy begrip "hibriede literêre oraliteit" (2002:105). In die lig van Johannes se boekkultuur, lyk dit of 'n mens eerder sal moet praat van 'n hibriede orale literêre teks.

${ }^{10}$ Hoewel Op 18 onlosmaaklik verbind is aan Op 17, word weens beperkte ruimte hier gekonsentreer op Op 18. Vir 'n analise van Op 17, kyk De Villiers (2007c) en die uitgebreide analise van die teks. Op 18 is, soos die volgende analise uitwys, as uitleg van die voorafgaande visioen, 'n duidelike eenheid náás Op 17 ten spyte van hulle noue samehang.
} 
ontwikkel. ${ }^{11}$ Die gehoor word steeds weer aan sekere fundamentele insigte herinner en dan deur nuwe insigte daaroor verder geneem.

Hierdie komposisie kan deur die plek van Openbaring 18 ná en voor ander hoofstukke as volg geillustreer word.

\subsubsection{Openbaring 18 as die begin van die Bose se einde}

Openbaring 18 word byvoorbeeld verbind met die vorige septette van oordeel in Openbaring 6-16 deur die herhaalde aankondiging van Babilon se oordeel (Op 14:8; 16:19). Die gehoor is deur daardie kort flitse voorberei vir wat in Openbaring 18 in detail uitgewerk word. Die prostituut van Openbaring 18 as meeloper van die bose triade (die draak en twee diere; Op 12-13) is voorts deel van 'n reeks van oordeelsgebeure in die visoenêre dele van Openbaring. Hulle vorm 'n konfigurasie van bose opponente van God wat die tweede helfte van Openbaring oorheers. Openbaring 18 is die inleiding tot die proses van oordeel oor hierdie hoofkarakters van boosheid. Sintagmatiese gesien, is Openbaring 18 'n hoogtepunt in die ontwikkeling van die verhaallyn.

Hierdie groter geheel met sy ekstreem bose en vernietigende karakters veroorsaak dat Openbaring 18 self ook buitengewoon negatief en intens is. Johannes komponeer 'n spiraalagtige ontwikkeling wat strek van die drie bose karakters tot die prostituut as die laaste bose figuur. Soos die spiraal opwaarts beweeg, word intense taal sterker en dringender. Die buitengewone skerp taal in Openbaring 18 en die toenemende uitbeelding van geweld en gebruik van geweldstaal hang dus saam met die klimaktiese ontplooing van die verhaallyn.

Die hegte komposisie van Openbaring 18 in hierdie groter geheel, veroorsaak verder dat sy tekening van die bose nie een-dimensioneel is nie, maar hoogs kompleks. Teen die tyd dat die vrou as vierde bose figuur reg is om van die toneel verwyder te word, weet die gehoor dat dit maar net een van vele gewelddadige karakters is. Soos sy tot niet gaan, draal die vraag na die lot van die ander in die agtergrond.

Vanweë sy strategiese ligging in die boek, is dit dus amper onvermydelik dat hierdie hoofstuk gewelddadig sal wees. Die konteks waarin dit voorkom, trek dit in in 'n netwerk van gewelddadige boosheid wat steeds weer spiraalagtig toeneem in geweld en boosheid.

\subsubsection{Openbaring 18 as die voorbereiding van die vredestyd}

Die gewelddadige karakter van die teks word deur ander patrone en konfigurasies uitgewys en beklemtoon. Die boek se fyn komposisie blyk uit die

\footnotetext{
${ }^{11}$ Vir voorbeelde hiervan, vergelyk die verskillende bydraes in De Villiers (2004a, 2004b, $2004 c$, 2004d) waarin verskeie dele van Openbaring vanuit 'n komposisionele hoek ontleed is.
} 
manier waarop simbole en tekseenhede paradigmaties in netjies gebalanseerde patrone bymekaar gebring is. Openbaring 18 moet byvoorbeeld verstaan word in die lig van die twee blokke inligting oor Babylon en oor die Nuwe Jerusalem wat die skrywer formeel met mekaar in 'n parallelle verhouding plaas deur die versigtig gekose strukturele merker

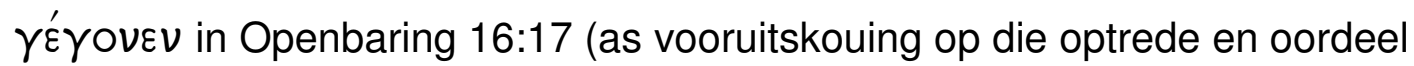
van Babilon) en $\gamma^{\prime} \varepsilon$ Yov $\alpha v$ in Openbaring $21: 6$ as voorbereiding vir die koms van die Bruid van die Lam (vgl ook Bauckham 1993:339). Ook die inhoude word wedersyds verder verduidelik (bv in die voorkoms en versieringe van die twee vroue-figure wat onder andere hulle gewelddadigheid en vredeskarakter simbolies uitbeeld). ${ }^{12}$ Die prostituut sit op baie waters (Op 17:1) wat die volkere simboliseer oor wie sy gewelddadig heers en wat sy met haar verleidelikhede as meelopers vir haar geweld betower en ko-opteer (Op $17: 15,18 ; 18: 23)$. Daarenteen is die Nuwe Jerusalem die plek van vrede waar die stad se poort nooit gesluit word nie, waar die nasies aan God heerlikheid en eer bring (Op 21:26) en waar die vrugte van bome langs die rivier van lewenswater tot heling van die nasies is (Op 22:1-2). Anders as Babilon, is Jerusalem die stad waarin daar geen ontroues, verraaiers, losbandiges, moordenaars, onsedelikes, bedrieërs, afgodsdienaars en leuenaars is nie (Op $21: 8) .{ }^{13}$ Hierdie is net een voorbeeld van Openbaring 18 se literêre funksie: Johannes wil die uitbeelding van 'n gewelddadige stad ekplisiet kontrasteer met die alternatiewe, vreedsame heilstyd wat met die koms van die bruid en die Lam aanbreek. Die twee visoene funksioneer dus op 'n paradigmatiese wyse saam as 'n kleiner literêre eenheid wat die boek se basiese boodskap van oordeel en heil tot voltooiing bring. ${ }^{14}$ Terwyl Johannes deur die gewelddadige Babilon vir sy gehoor verduidelik waarvan hulle hulle moet distansieer, illustreer die Nuwe Jerusalem vir hulle die aard van 'n outentieke bestaan. ${ }^{15}$ Terwyl die Nuwe Jerusalem die epitomie van die nuwe lewe in 'n

\footnotetext{
${ }^{12}$ Daar is ander verbindingslyne wat wys die kompleksiteite van die boek se komposisie bevestig. Beale (1999:889-90) kontrasteer byvoorbeeld Openbaring 17 verder ook met die vrou in Op 12. Hierdie groter lyne is egter sekondêr aan die onmiddlellike parallellie tussen die prostituut en die bruid van die Lam.

${ }^{13}$ Kyk Boesak (1987:133) se boeiende uiteensetting hoe hierdie lys ten nouste met die stryd van die kerk teen die absolute aansprake van hulle teenstanders verbind is.

${ }^{14}$ Daar is byvoorbeeld ook die kontras tussen die eskatologiese koms van die dier in Openbaring 17:8a en die hemelse herkoms van die Nuwe Jerusalem, (kyk verder Bauckham 1993:436).

${ }^{15}$ Kyk Bauckham (1993:7). As teenpool van en parodie op die Nuwe Jerusalem is Babilon 'n illustrasie van die keuse wat gelowiges vir hulle spirituele reis het: hulle is óf navolgers van die Lam waarheen hy ook al gaan (Op 14:4), óf hulle volg die bose wat na die verderf gaan (Op 17:11). Hierdie uiteindelike perspektief op die einde, op die paradys en sy teenpool, gee aan die verhaal van Openbaring kleur en aan sy individuele teksdele betekenis.
} 
paradys-konteks is, is Babilon die voorbeeld van die bose in al sy kompleksiteite.

\subsection{Tegnieke en taal}

Daar is ook ander aspekte van Johannes se skryfkultuur wat lig op Openbaring 18 as geweldsteks werp. Johannes het 'n sy stewige kennis van literêre tegnieke wat aan sy teks 'n besondere poëtiese en estetiese kwaliteit verleen. Voorbeelde van sy stylfigure sluit in chiasmes, ringkomposisies, parallelismes, paranomasia, alliterasie, parechesis, homoioteleuton, onomatopeë, epanadiplosis, simileë en metafore (vgl bv Thompson 1990:4650 ), hoewel veral die gebruik van ironie en parodie die oog vang. Met ironie en parodie moet 'n mens skerpheid verwag. Omdat dit uitgebreid in Openbaring 18 voorkom, gee dit aan die gedeelte verdere intensiteit. Deur sy literêre tegnieke is Johannes as skrywer in hierdie gedeeltes op die aanval. $\mathrm{Hy}$ is besig om sy teenstanders te ontmasker. Hoewel dit nie noodwendig oral in die boek geweld hoef in te sluit nie, skep dit 'n agonistiese konteks waarin die skrywer "met alle geweld" sy punt wil maak en sy teenstander wil uitskakel. In Openbaring 18 is die skrywer sekerlik besig om geweld deur sy literêre tegnieke van ironie en parodie uit te wys, soms deur self gewelddadige taal te gebruik - soos hier onder uitgewys sal word.

Nou verbind met Johannes se gebruik van literêre tegnieke, is ontwikkelinge binne die navorsing insake Johannes se grammatika. Vir 'n lang tyd het sy reputasie as skrywer gely onder sy gewaande taalkundige flaters en sogenaamde Griekse blapse. ${ }^{16}$ In onlangse navorsing het hierin ook 'n ommekeer ingetree. 'n Beduidende aantal navorsers argumenteer nou dat Johannes in werklikheid doelbewus sy taal op 'n behendige manier aangepas het om sy opponente by te kom.

Vroeë tekens van hierdie nuwe ontwikkeling was opmerkings van Laughlin in sy dissertasie dat Johannes nie dom was nie, maar doelbewus sy styl aangepas het "to reproduce the manner and spirit of the ancient Prophets; it was not through ignorance of correct Greek usage."17 Dit was egter

\footnotetext{
${ }^{16}$ Kyk Mussies (1971:3-12) vir `n historiese oorsig. Die negatiewe oordeel oor Johannes se taal is volgens Callahan (1959:454) gebaseer op die swak vertalingsproses, die nalatigheid van die skrywer of 'n plaaslike dialek van 'n groep waaraan die skrywer behoort het. Hy argumenteer aan die hand van verskeie voorbeelde (teen Charles) dat heelwat van die vermeende probleme veroorsaak is deur die invloed van die Septuaginta. Die unieke taalgebruik is egter, soos later hier onder sal blyk, nie bloot net hiervan die gevolg nie. Dit kan ook nie 'n gevestigde dialek wees nie, omdat daar geen ander getuienis van sulke taalgebruik is nie.

${ }^{17}$ Aangehaal by Mussies (1971:8). Vir ander voorbeelde, vroeër en later, vergelyk Callahan (1995:458-9). Hy verwys onder andere na sulke gesaghebbende eksegete soos Beckwith, Farrer, Beale en Kraft.
} 
Thompson (1990:184) wat die taalgebruik 'n angel gegee het, toe hy geargumenteer dat die unieke Semitiese Grieks van Johannes die Hellenistiese diskoers van die status quo van sy tyd doelbewus wou ondermyn. Met allerhande taalverwringings en manipulasie (woordspelinge, ironie, antitese's) bevraagteken Johannes aanvallend die bestaande orde. Die argument is deur ander navorsers verskerp deur taal self as terrein van stryd uit te wys (vgl Maier 2005:109 en die literatuur daar). Johannes sou deur sy polemiese intensie gedryf word om met opset 'n verminkte, afwykende taal aan te bied. Hier word taal die strydbyl self, die vlymskerp mes waarmee die stryd aangepak word. ${ }^{18}$ Callahan (1995:463-4) skryf aldus:

The language of the text - its discourse, the word of God - is the struggle. The terrain of contestation is the discourse itself .... John's grammatical howlers are intentionally designed to alert listerners that, upon entering the realm of apocalyptic language, they are in a place that contests accepted ways of naming and organizing the world.

"Struggle", "contestation", "howlers" and "contests" is veelseggende begrippe wat iets weergee van die hitte van die stryd wat 'n mens ook in 'n gedeelte soos Openbaring 18 moet verwag. Johannes ondermyn volgens hierdie teorie die taalpraktyk van die bestaande orde as 'n protes en waarskuwing teen hierdie orde en sy gewelddadige karakter. Hiermee word nie net aan Johannes 'n besondere insig in die funksie van taal toegeskryf nie. Dit wys ook hoedat sy taalgebruik reeds 'n polemiese karakter kry. Johannes se wapen is sy taal en sy teiken is die sosiale diskoers met wie polemies meeding.

Dat hierdie nuwe insigte nie heeltemal vergesog is nie, blyk uit 'n ander interessante aspek van Johannes se hantering van taal. Hy karakteriseer naamlik die identiteit en betekenis van sy bose karakters aan die hand van hulle brute, lasterlike taalgebruik. Hulle spreke of hulle "taal" verraai wie hulle werklik is. Die tweede dier uit die aarde, hoewel hy bedrieglikerwys soos 'n lam lyk, word deur sy "praat' as 'n draak ontmasker (Op 13:11). Deur die simboliek word hy in sy spreke as monsteragtig uitgebeeld. Dit, weer,

\footnotetext{
${ }^{18}$ Thompson (1990:184) meen dat hierdie arbitrêre omvorming van taal en grammatika in die plek kom van duidelike oorsaaklike lyne - net soos wat gebeur in Ovidius se Metamorfose (verwysende na navorsing van Massey oor Ovidius). "The playful language of the seer ... especially endangers the fixed order. Through such verbal manipulation what appears publicly contrasts with what reality is: the wealthy are not really wealthy, those of high rank are not really of high rank, and the glories of Roman peace and prosperity mask satanic forces soon to be defeated." Hiermee word die parodiërende en ironiserende karakter van sy taal onderstreep. Vergelyk verder hier onder (maar ook die interessante praktiese besinning oor die gevolge hiervan vir die kanonieke status van die teks by Knight 1999:26).
} 


\section{Die ontmaskering van die bose}

kontrasteer met die volgelinge van die Lam wat rustig met harpebegeleiding tot eer van God 'n "nuwe lied" sing in sulke gedeeltes soos Openbaring 14:3. In hulle mond word geen "bedrog" gevind nie (Op 14:5). Selfs die draak se standbeeld praat gewelddadig en sy spreke het ekstreme geweld tot gevolg: dié wat nie sy bevele uitvoer nie, word summier gedood (Op 13:14). Ook die prostituut in Openbaring 17:3 sit op die dier wat bedek is met lasterlike name. Selfs die versigtig gekose simboliese name waarmee die bose karakters benoem word wys hulle verdorwe aard uit. Die beste voorbeeld hiervan is die naam Abaddon/Apollion vir die onderaardse engel in Openbaring 9:11. ${ }^{19} \mathrm{Hier}$ verraai sy naam (die vernietiger) sy vernietigende, gewelddadige karakter (Prigent 2001:317). Nie net toon Johannes hiermee sy bedrewenheid deur 'n woordspeling en 'n dubbele naam (wat sy gehoor dubbel inlig) nie, maar wys dit terselfdertyd hoe sy taal op wesenlike aspekte handel oor geweld.

Hier is 'n laaste opmerking nodig. In die navorsing is die implikasies van Johannes se simbole vir sy bose karakters nie altyd voldoende verreken nie. Vir hom is die bose in sy primordiale staat 'n groot vuurrooi draak wat selfs 'n derde van die sterre in die hemel met 'n klap van sy stert op die aarde kan smyt (Op 12:4) en wat in sy wreedheid reg staan om 'n uitgelewerde vrou aan te val en haar baba by geboorte "te verslind" (Op 12:4). Hierdie kontras tussen wilde diere en humane karakters is natuurlik tipies apokalipties, maar in Johannes meer intens en beslis meer gewelddadig. ${ }^{20} \mathrm{Hy}$ stapel sy gewelddadige simbole op wanneer hy twee wilde diere by die draak voeg om nie eers te praat van die talle koppe en horings waarmee hy hulle gewelddadige mag uitbeeld nie. Deur lokalisering word die kontraste verder geïntensifieer. Die wilde diere word verbind met die onder-aardse diepte en met die see as plekke van onheil (Op 12-13; 20:2).

Geweld deurspek die karakters reeds op die vlak van hulle taal, voorkoms en woonplek. Vir Openbaring 18 is die keuse van Babilon as simbool vir Johannes se vyand, veelseggend. Babilon, deur wie se toedoen mense oor die hele aarde gesneuwel het (Jer 51:49), verteenwoordig vir gelowiges in sy tyd by uitstek die groot en gewelddadige vernietiger van God se volk. Deur hierdie simbool is die dekor uitgeplaas vir tonele van verwoesting en geweld.

\footnotetext{
${ }^{19}$ Vergelyk ook byvoorbeeld Op 13:1, 5 vir die dier se lasterlike name en Op 12:9 en 20:2 vir die draak se veelseggende name. Die implikasies van hierdie opmerkings is soveel groter in die lig van die belangrike rol van name in Openbaring.

${ }^{20}$ In die Diere Apokalips in 1 Henog is daar toenemende regressie in die menslike geskiedenis vanaf die aartsvaders, tot die volk Israel as lam, tot die ramme en dan die wilde diere van die eindtyd. Johannes skep 'n baie sterker kontras as so 'n geleidelike degenerasie.
} 


\subsection{Boekkultuur}

Hoe versigtig Johannes se teks tot op die enkel woorde na, gelees moet word, moet nou met ' $n$ omdraai geïllustreer word. Dit is nodig om te toon hoe presies sy gelaaide en berekende teks gelees moet word om die geweld daarin goed uit te lê. Johannes se gevoel vir taal maak sin in die lig van die feit dat Openbaring ' $n$ boek is wat origens breedvoerig 'n boekkultuur suggereer. Die teks bevat verbasend baie verwysings na lees, skryf en boeke. Dit is deurdrenk van sinspelinge op bekende skriftelik tradisies (veral die Hebreeuse profete). ${ }^{21}$ Opvallend is verder hoe Openbaring gekonsipieer is as 'n boek waarin ander boeke opgeneem is. Boonop speel hierdie boeke ' $n$ seminale rol in die struktuur van die boek (Barr 1986; 2003:11-23). Aan sy begin en einde word Openbaring 'n "boek" genoem (Bıß入íov; Op 1:11; 22:7, $9,10,18,19)$. Hy verwys na 'n paar boeke in sy teks en gebruik hulle selfs om die teksinhoud te help struktureer. Aan die begin van die visioenêre deel is daar in die troonvisioen die verseëlde boek (Op 4-5; $\beta ı \beta \lambda i ́ o v)$. Die tweede groot afdeling fokus in die middelstuk op die kleiner boekrol (Op 10; $\beta ı \beta \lambda \propto \rho i ́ \delta ı v)$, terwyl die laaste deel weer die boeke van die laaste oordeel as belangrike motief bevat (Op 21:27, maar kyk 17:8; 20:12; tò ßıß $\left.\beta ı \beta \lambda^{\prime} \alpha\right)$. In hierdie eindtonele word selfs God voorgestel as 'n ywerige "boekhouer" en skrywer wat boek hou van menslike dade met die oog op die finale oordeel. Daarbenewens word daar sewe keer aan gemeentes "geskryf" (Ypółov; Op 2:1, 8, 12, 18; 3:1, 7, 14). Die siener word as skrywende karakter voorgestel. Twee keer word hy aangesê om 'n "boek" te skryf (Op $1: 11,19)$, maar hy word nie toegelaat om te "skryf" wat die sewe donderslae onthul nie (Op 10:4 - twee verwysings!). In Openbaring 14:13 gee 'n hemelse stem hom opdrag om 'n makarisme neer te skryf en aan die einde kry hy van 'n engel dieselfde opdrag (Op 19:9). Name van uitverkorenes word in die lewensboek "geskrywe" (Op 13:8; 17:8; 20:15; 21:27). Só gewoon en gevestig is die boekkultuur dat die motiewe van "boeke" en "skryf" selfs simbolies gebruik word. Daar is die metafoor van 'n boek wat opgerol word (Op 6:14) en name wat op klippe, 'n pilaar en voorkoppe geskryf word (Op 2:17; 3:12; cf $14: 1 ; 19: 16 ; 21: 12)$.

\footnotetext{
${ }^{21}$ Die boek verraai ook kennis van gewedldadige Griekse mitologie. Vergelyk byvoorbeeld Bauckham (1993:197-8) oor Johannes se oorname van die geboorte van Apollo en sy oorwinning oor Puthoon. Wanneer Johannes die mite in Op 12 opneem, polemiseer hy volgens Bauckham (1993:195) met die heiden-kultusse in die sewe stede. "John was fighting on several fronts, and in chapter 12 required a symbol of evil more fundamental than the imperial cult" (Bauckham 1993:196 n 77). Hierdie polemiek met heiden-kultusse onderstreep die veelkantige aard van sy agonistiese teks, maar die gewelddadige Apollo mite illustreer ook in watter geweldskonteks Johannes sy teks moes konsipieer.
} 
Hierdie opmerkings oor 'n skryfkultuur as konteks van Openbaring, kry nou 'n ekstra dimensie wanneer Johannes skryf dat niks by sy teks gevoeg of

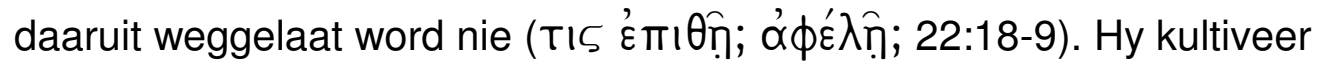
hiermee bewustelik die gedagte by sy lesers dat sy teks tot in die detail besondere seggingskrag het. Dit word bevestig deur opmerkings dat sy teks gelaai is met dieper betekenisse. Hy maak trouens sy lesers reeds aan die

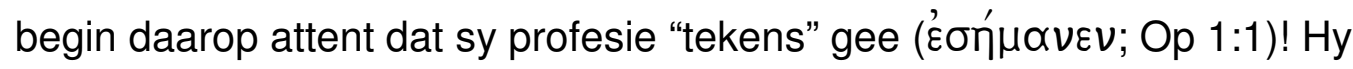
verwys uitdruklik na sommige simbole se "verborgenheid" (Op 1:20;17:5, 7; 19:8b). Heel plasties vertel hy in Openbaring 17:6 dat hy verstom was ("uitermate verslae" in die eerste Afrikaanse vertaling) oor die visioen van Babilon met die opmerking dat 'n engel dan vir hom "die verborgenheid" daarvan uitlê. Sy verstomming "convey(s) his puzzlement over the meaning of the vision" (Aune 1998:938). Ook hier het sy teks dus dieper waarhede wat aan die gehoor uitgelê moet word.

As voorbeeld is dit nuttig om na te gaan hoe Johannes naas Babilon 'n hele reeks van stede in sy teks opneem. Hulle is almal gewelddadig en boos. In Openbaring 11:8 word die groot stad waar die twee getuies profeteer, naas Sodom, Egipte en Jerusalem genoem. Die bose stad wat die twee getuies vermoor, verwys volgens hom "geestelik" na Sodom en Egipte, maar is ook terselfdertyd die plek is waar die Here gekruisig is (Op 11:8). ${ }^{22}$ Hulle is gelaaide simbole wat plekke en instrumente van traumatiese geweld teen die volk van God verteenwoordig. Wanneer Babilon paradigmaties in hierdie fyn konfigurasie van simbole gelees word, is dit sonder meer duidelik watter intense gevoelens by die gehoor aanwesig was teen die tyd dat hulle die ontplooing van die verhaallyn in Openbaring 18 sou meemaak.

Wanneer Johannes dus oor geweld skryf, moet die web van motiewe en simbole wat daarmee verbind word, steeks verreken word. Juis omdat hy so bedrewe is, vra dit van die uitlegger sensitiwiteit vir die teks tot in sy kleinste detail. Al hierdie verbindingslyne en aspekte moet nagevors word om die ryke betekenis van Openbaring 18 uit te spel.

\section{AGONISTIESE TAAL IN OPENBARING}

Die apokaliptiese oorlogstaal van Openbaring het by definisie al 'n duidelike agonistiese karakter en staan dus in die teken van stryd. Apokaliptiese tekste vertel van die groot konflik tussen die goddelike en die bose. Maar apokaliptiese tekste pas op hulle beurt in in die algemene agonistiese aard

\footnotetext{
${ }^{22}$ Net so intens is sy beskrywing van die prostituut. Sy sit op baie waters (Op 17:1), op 'n skarlakenrooi dier (Op 17:3) en ook op sewe berge (Op 17:9). Ook sterk gelaaid is simboliese beskrywing van die sewe konings van Op 17:10-11. Vergelyk verder hieroor De Villiers (2002c:106-7, 112-3).
} 
van sosiale diskoerse in Johannes se tyd. Ong (1981) byvoorbeeld gewys hoe diskoerse sedert die antieke tot selfs in onlangse tye op verskeie gebiede in 'n manlike konteks gefokus was op die uitskakeling van die opponent as die hoogste ideaal. ${ }^{23}$ Reeds die antieke retoriek was byvoorbeeld deurdrenk met 'n benadering waarin ander deur versigtig gekose argumente afgekraak word sodat die eie standpunt kan seëvier. ${ }^{24}$ Die patriargale karakter van die samelewings het die agonistiese kultuur verder bevorder. Kulture het allerhande rituele ontwikkel om mans die kans te gee om hulle groter mag oor ander mans te toon. Johannes se agonistiese taal, soos blyk uit sy vrouekarakters word deur sy patriargale kultuur gestut (vgl bv Pippin 1995 en 2005). Vanuit 'n hermeneutiese hoek gesien, staan sulke tekste in spanning met sosiale diskoerse in ons kontemporêre postmoderne kontekste met hulle ingesteldheid op 'n ireniese openheid.

Openbaring dekonstrueer egter by tye sy agonistiese teks. Johannes se sterk reaksie teen sy opponente sluit byvoorbeeld fisieke gewelddadigheid uit. Sy wapen teen die dwingende mag van die maghebbers is ' $n$ gelowige getuienis wat hy in Openbaring 12:11 uitspel: "Hulle het die bose oorwin deur die bloed van die Lam en deur die woord van hulle getuienis, en hulle het tot die dood toe hulle lewe nie liefgehad nie" (Op 6:9; 11:7).

Tog bly Johannes se taal grotendeels agonisties en met sy literêre behendigheid span hy allerhande tegnieke in diens van sy agonistiese skryfstyl in. Die getuienis waarmee die bose aangespreek word, is vlymskerp en dodelik. Dit blyk in die belangrike verhaal oor die kerk as die twee getuies in Openbaring 11 waar vuur uit hulle mond gaan om hulle vyande te verslaan (Op 11:5). Die taal is skerp, met selfs die byvoeging, "en as iemand hulle wil beskadig, moet hy op dieselfde manier doodgemaak word." ${ }^{25}$ Maar selfs hier moet weer verder gekwalifiseer word. Die twee getuies verkondig God se

\footnotetext{
${ }^{23}$ Studies soos dié van Leung (2002); Rees-Miller (2000); Tannen (2002) en veral Hawhee (2002) skryf oor agonistiese taal vanuit linguïstiese hoek. Hierdie studie, wat weens ruimte nie in die artikel verwerk kan word nie, beloof om interessante insigte te gee in die aard van Openbaring. Die tipe retoriek en argumente wat in 'n agonistiese situasie funksioneer verdien meer aandag in die navorsing. Kyk as 'n eerste voorbeeld Maier (2002:102-3). Hy gebruik Ong om veral die sterk agonistiese aard van Openbaring as mondelinge teks te bespreek.

${ }^{24}$ Vergelyk Connors (1997:26-8). Hy wys op die agonistiese aard van die ouer opvoedkundige benaderings waarin kritiek op die opponent aan die orde van die dag was. Dit is volgens hom eers deur die teenwoordigheid van vroue dat opvoeding in die laaste twee eeue ' $n$ meer ireniese karakter aangeneem het en van sy agonistiese verlede wegbeweeg het. Die probleem met 'n agonistiese aanpak is dat dit kennisverwerwing verhinder omdat dit die opponent verwerp eerder as wat dit met nuttige meningswisseling in 'n gesprek met hom/haar tree.

\footnotetext{
${ }^{25}$ Bauckham (1993:274). Vergelyk hierdie verhaal as 'n illustrasie van die kerk se taak tot wêreldsending. Hierdie openheid en missionêre gerigtheid van Op word in onlangse navorsing soms en op kritieke punte buite rekening gelaat.
} 


\section{Die ontmaskering van die bose}

oordeel in sterk, dramatiese vorm met die uitdruklike doel on hulle op te roep tot bekering, wat dan ook inderdaad aan die einde plaasvind (Op 11:13). Die plastiese beskrywing van die getuies se magtige optrede (Op 11:5-6) funksioneer in die raamwerk van hierdie bekeringsoproep. Die agonistiese taal van Johannes is nie bloot op die willekeurige en hatige uitskakeling van die opponent gerig nie, maar is sterk, rigterlike taal om die opponent se destruktiewe en gewelddadige leefwyse aan te spreek.

Die gedeelte is origens sekerlik problematies, want die twee getuies word ook gewelddadig vooorgestel. Mense wat hulle kwaad aandoen, moet sterf. Hulle hou die reën terug, verander water in bloed en laat plae op die aarde los (Op 11:5-6). Selfs al dien dit 'n oproep tot bekering en word hier Exodus-terminologie gebruik wat aan die teks metaforiese kwaliteite gee, dra die teks onmiskenbaar die agonistiese kwaliteite van die destydse sosiale diskoers. Wel is dit opvallend dat dit nie die magsdade van die getuies is wat die werklik ommekeer in die stad bring nie. Dit is hulle dood en God se bevestiging in hulle opstanding wat die bekering van die stad tot gevolg het. In die sin sou die verhaal geïnterpreteer kon word as 'n vreeslose oproep van gelowiges aan ander om deur die nuwe uittog die wêreldstad agter te laat sodat die plae hulle nie tref nie.

Die agonistiese verhaal van die twee getuies in Openbaring 11 illustreer origens die die gebruik van parodie, ironie, sarkasme en hiperbole (Aune 2003:237). In die verhaal is daar hiperboliese beskrywing van die getuies se buitengewone mag, die parodie op die magtige stad deur die benaming van Egipte en Sodom, asook die ironie dat hulle hulle moord van die getuies as 'n oorwinning met vreugde vier terwyl hulle eintlik 'n oordeel oor hulleself gebring het.

Hier is 'n paar kort opmerkings oor ironie en parodie nodig, juis omdat beide hierdie literêre tegnieke die interpretasie van Openbaring bepaal. Openbaring se herhaalde ironiese taalgebruik kan nie gelykgestel word aan die meer gefokusde vorm van ironie wat op sinsvlak funksioneer en wat uitsluitlik linguïsties bepaal is. Hierdie ironie behels 'n stelling wat die teenoorgestelde beteken van wat letterlik gesê word. ${ }^{26}$

\footnotetext{
${ }^{26}$ In die Nuwe Testament word Paul se snydende opmerking teenoor die Korintiërs as voorbeeld genoem ("Julle wat so verstandig is, verdra mos geredelik die dwaas"; 2 Kor 11:19, maar ook 2 Kor 11:8: "Ander gemeentes het ek beroof deur vergoeding te neem om julle te bedien"). Vergelyk vir voorbeelde Aune (2003:237) en sy verwysing, o a na Aristoteles se Rhetorica ad Alexandrum 21 en sy bespreking van Gal 1:6-8. Aune onderskei byvoorbeeldligte ironie van"harde ironie" (sarkasme) met verwysings na Schlier, Betz, Longenecker en Nikolakopoulos. 'n Uitspraak kan deur 'n konkrete situasie ironies word, soos wanneer iemand met woedende lyftaal uitroep: "Hoe bly is ek nou!" In hierdie geval moet 'n mens die persoon waarneem om die ironie van die taalgebruik te herken. Die vorm van ironie is ook bekend as situasionele ironie.
} 
Ironie in Openbaring word meestal in 'n wyer sin van die woord gebruik. Dit verwys onder meer na 'n narratief waarin die verloop van gebeure die intensie van die karakters frustreer (Friesen 2006:133). ${ }^{27}$ Dit toon verwantskap met dramatiese of tragiese ironie wat in dramatiese tekste voorkom wanneer 'n gehoor gebeure beter as die karakters self kan peil. ${ }^{28}$ ' $n$ Analise van Openbaring wys dit drup van ironie. Dit skets ironies die mag van die bose triade (die draak en die twee diere) wat wêreldwyd as volg vereer word. "Wie kan met die dier vergelyk word? En wie kan teen hom oorlog voer?" Hierdie bose konfigurasie simuleer die taal van die goddelike om hulle houvas op hulle volgelinge te versterk. Die draak het daarom 'n messiaanse propagandis wat soos Christus fataal verwond word, maar mirakelagtig daarvan herstel (Op 13:3, 12, 14). Ook die tweede dier, die profetiese figuur roep mense op om die dier wat hom goddelike eer aanmatig, te aanbid (Op 14:7). Teenoor die onberoulike wêreld en sy aanbidding van die bose, staan die skrywer van Openbaring en sy volgelinge wat uit hulle kennis as binnestaanders besef dat slegs God, die Almagtige (Op 1:8) aanbid moet word (Op 14) en dat die bose karakters se dae getel is. Hulle weet selfs meer as hulle mede-Christene wat ook met hierdie bose karakters heul (Jezebel en haar volgelinge in Op 2:20). Die teks ontmasker die opponente as bedrieërs. Die volgelinge van die bose dink hulle het ' $n$ unieke meester, maar hulle besef nie dat sy skynbaar oordonderende oorlogvoering in werklikheid futiel is nie. Gelowiges, daarenteen, herken deur die teks die ware toedrag van sake en kyk dwarsdeur die aansprake van die bose. Dus, binne hulle situasie werk hierdie boek se taal besonder ironies. Dit is agonistiese taal wat die opponent in sy gewelddadige boosheid wil ontmasker.

Nou samehangend hiermee is die skrywer se gebruik van parodie. Parodie in die enger sin wys op twee sake wat in 'n oënskynlik weersprekende betekenis met mekaar in verhouding geplaas word (Bühlmann

\footnotetext{
${ }^{27}$ Somtyds is die ironie van ' $n$ hele teks so subtiel dat dit nie op die eerste oogopslag duidelik is nie. Een van die beroemdste voorbeelde in die literêre geskiedenis is Daniel Defoe, die sewentiende / agtiende eeuse Engelse skrywer van die befaamde verhaal Robinson Crusoe. Hy was ook die skrywer van 'n aanvanklik anonieme pamflet The Shortest Way with the Dissenters. In die werk vra hy skynbaar vir 'n genadelose hantering en uitwissing van die opponente (dissenters) van die Anglikaanse kerk, maar in werklikheid is dit 'n skerp ontmaskering van priesterlike hoogheilighed en barbaarse onverdraagsaamheid. Ironies genoeg, het sy verhaal aanvanklik sterk applous uitgelok - juis van die kerklike magshebbers - totdat die ironies karakter daarvan herken is met die bekendmaking van die skrywer se identiteit as 'n dissenter. Slegs wie die historiese situasie ken, sal die ironie in die teks herken.Die effek van hierdie ironie is van belang om Openbaring te verstaan: Defoe se uitbundige lof is, teen die letterlike sin van die teks in, in werklikheid snydende, ontmaskerende kritiek van die karakters wat in die teks aangeprys word.

${ }^{28}$ In Oedipus Rex, byvoorbeeld, is Oedipus self die moordenaar wat hy aan die soek is. Hy en die ander karakters, ironies genoeg, besef dit nie.
} 


\section{Die ontmaskering van die bose}

1994:98). Dit is "'n belaglik makende nabootsing" (HAT). ${ }^{29}$ Met parodie maak Johannes elke absolute aanspraak van die Bose belaglik en keer dit op sy kop. Teenoor al die aansprake van die konings van die aarde staan byvoorbeeld die status van God as die Pantokrator (Op 1). Die beskrywing van Jesus as Menseseun in al sy glorie (Op 1-2) is 'n parodie op die keiserlike aansprake. Ook hier wil die agonistiese taal die teenstander ontmasker en sy ware identiteit uitspel.

Dit is teen die agtergrond van hierdie literêre behendigheid van Johannes en sy agonistiese taal dat Openbaring 18 gelees moet word. Dit geld ook van die nie-gewelddadige getuienis-lewering van die twee profete in Openbaring 11 wat skynbaar probleemloos inpas in die antieke agonistiese diskoers. Waar dit nie gebeur nie, word die teks vir die moderne leser deur harde beskrywings gekompromiteer.

In Openbaring moet 'n mens dus weens die agonistiese taalgebruik en die daarby passende tegnieke, buitengewone skerp taal verwag. Die taal moet nie kru gelees word nie en dus misverstaan word nie. Wie die literêre konteks van hierdie gedeeltes ken en hulle lees in die lig van die boek se niegewelddadige karakter, sal die gewelddadige taal daarom ironies en parodiërend lees. Dit is veral waar van Openbaring 18, wat nou verder in diepte bespreek sal word.

\section{DIE KOMPOSISIE VAN OPENBARING 18}

Die koherensie van Openbaring 18 was nie altyd so deursigtig vir navorsers nie. Openbaring 18 is reeds deur Charles (1920:93) as chaoties beskou oor verse wat volgens hom deurmekaar geraak en op verkeerde plekke beland het. $^{30}$

'n Lineêre lees van die teks is inderdaad problematies. Die gedeelte begin met die aankondiging van Babilon se val (Op 18:1-3), waarna, in 'n sterk skuid, 'n oproep volg aan "my volk" (vers 4) tot distansiëring en selfs vergelding van die stad (Op 18:4-7a). ${ }^{31}$ Daarna verdwyn die volk heeltemal

\footnotetext{
${ }^{29}$ In die postkoloniale teksanalise word ironie en parodie in sy breër sin veral binne 'n sosiale diskoers van hoogs ongelyke, asimmetriese verhoudinge geplaas. Die bestaande sosiale diskoers word deur ironie en parodie ondergrawe en as te ware onttroon om 'n alternatiewe diskoers op te stel en te verdedig (Maier 2002:183).

${ }^{30}$ Charles (1920:93) dink veral dat verse 14 en 20 (asook sommige frases in 22-23) nie in hulle huidige konteks pas nie. Aune (1998:976) is minder skerp, maar ook krities: "As so often in Revelation, the formal structure imposed on the material does not cohere well with an analysis of the content." In sy bronne-analise (1998:983-4) vind hy ander probleme wat wys dat die gedeelte ' $n$ samevoeging van uiteenlopende bronne is en dus nie 'n sterk koherensie het nie.

${ }^{31}$ Selfs die orde in verse 4-8 as kleiner eenheid word as verwarrend beskou (vgl Kiddle 1940:365).
} 
van die toneel. Onverwags verskyn verskeie groepe meelopers van Babilon op die toneel met drie trenodes oor die gevalle stad. Dan skielik verander die toneel weer weg van hierdie meelopers met ' $n$ oproep aan die hemel en heiliges om die val van die stad te vier (Op 18:20) voordat uiteindelik weer na 'n beskrywing van die stad se val teruggekeer word, hierdie keer egter met ' $n$ profetiese handeling (Op 18:21-24). ${ }^{32}$ Vers 14 bevat voorts 'n opmerking direk aan Babilon self wat na die voorafgaande lys van produkte uit plek is. Vers 20 lyk weer problematies omdat dit direk volg op die matrose se trenode oor Babilon. Hierdie seelui kan tog nie nou skielik in vers 20 die hemele tot vreugde oor Babilon se val oproep nie (Bauckham 1993:341). Ook die wisselende gebruik van die verlede en toekoms trek die aandag. Die oordeel oor Babilon in Openbaring 18:4-8, die trenode van die konings (Op 18:9-10) en Openbaring 18:21 word in die toekoms geplaas, terwyl die matrose dit in die verlede plaas (Op 18:17b-19). Prigent (2001:499) skryf hieroor, "The text thus hesitates constantly between what is accomplished (the past and the present tenses) and the future. Is this due to clumsiness on the part of the author? Undoubtedly. But it is surely not a sign of incoherence nor a proof of different sources." Hy maak dus op een of ander manier sin uit die deurmekaar tye, maar dink tog die skrywer is onhandig en lomp.

Die gewaande "lompheid" kan nie, soos Charles wou, deur herrangskikking ${ }^{33}$ van die teks opgelos word nie, want die teks verskyn in die beste manuskripte (Müller 1995:307). 'n Noukeurige lees van die teks sal egter wys dat daar 'n duidelik alternatief is. Dit is naamlik 'n netjiese ringkomposisie met kleiner patrone ${ }^{34}$ (Bauckham 1993:338-43; Giblin 1991:166-72). Om dit te kan doen, moet ' $n$ belangrike hermeneutiese skuif gedoen word, want dit vra van die eksegeet om Openbaring nie lineêr te lees

\footnotetext{
${ }^{32}$ Bauckham (1993:342) vind die logiese voortgang op 'n heel ander vlak: Mense word aangesê om Babilon te verlaat (4b-5), 'n oproep tot wraak volg (6-7a), dan word die wraak uitgevoer (7b-8), groepe treur terwyl Babilon brand (9-10; 11-13; [14: invoegsel]; 15-17a; 17b19), en die hemel word tot vreugde opgeroep (20). Terwyl hierdie analise nuttiglik die motief van die brand as 'n deurlopende draad in die meeste dele uitwys, dek dit duidelik nie alle dele nie en werk dit ook nog met invoegsels.

${ }^{33}$ Die gesprek oor die hoofstuk se inkoherensie loop oor baie eeue en is al in die vroegste tye gevoer. Müller (1995:307-8) verwys byvoorbeeld na Vitringa wat reeds in die 18e eeu die vers tussen verse 23 en 24 wou invoeg.

${ }^{34}$ Lohmeyer (1953:148) beskryf byvoorbeeld die korter Op 18:21-24 as "vielleicht dem kunstvollsten und erschütterndsten der ganzen Apc ..." Hy onderskei hier verder 7 liedere met 'n vaste aantal elemente. Sulke opmerkings suggereer dat 'n kunstige ordening ook op makro-vlak kan gebeur.
} 


\section{Die ontmaskering van die bose}

nie. ${ }^{35}$ 'n Ringskomposisie is veral 'n voorbeeld van 'n nie-lineêre lees van die teks.

In die enkele gevalle waar die ringskomposisie in die navorsing tot dusver wel herken is, is dit meestal deur inhoudelike kriteria uitgewerk. Bauckham haal byvoorbeeld 'n A-B-A' patroon uit die hoofstuk (1993:33943), ${ }^{36}$ maar oorweeg nie heelwat ander formele aanduidings wat op verskeie vlakke die teks as geheel en kleiner dele daarvan in groter en in kleiner ringskomposisies saambind nie. Dit is egter veral op formele vlak dat die ringskomposisie uitgewys kan word. 'n Analise van die teks sal naamlik toon dat Johannes formeel sy materiaal op 'n nie-lineêre manier in 'n ring struktureer om groepe karakters te gebruik om verskillende perspektiewe op Babilon as gewelddadige stad te gee.

'n Formele analise (sien die tabel aan die einde) sal uitwys dat Johannes die val van die stad met agt eenhede beskryf. Hierdie agt eenhede volg in 'n patroon van $A, B, C, D$ en dan terug in $D^{\prime}, C^{\prime}, B^{\prime}, A^{\prime}$. Met $A$ en $A$ ' omraam hy die gedeelte, terwyl $C / C^{\prime}$ en $D / D^{\prime}$ die binneste gedeelte vorm. Die twee dele wat die koherensie van die hoofstuk volgens tradisionele uitleg die meeste versteur het, vorm as B en B' 'n netjiese eenheid in hierdie groter geheel. Dit agt eenhede is paradigmaties aan mekaar verbind, en moet steeds gesamentlik in pare gelees word om sin te maak.

\section{PERSPEKTIEWE OP GEWELD}

Die ring komposisie van Openbaring 18 onthul dat die skrywer die val van Babilon eers aan die orde stel voordat hy twee perspektiewe daarop wil bekyk. In die raam van die ringskomposisie (A/A') bied hy eers 'n perspektief op Babilon se radikale magsverlies en die oorsake daarvan. Hy kontrasteer dan in die middelstuk 'n goddelike perspektief (B/B') met 'n aardse perspektief (C / C' en D / D') op die gevolge van die val. Hierdie radikale ommekeer en die twee perspektiewe daarop sal nou bespreek word.

\footnotetext{
${ }^{35}$ Die sterkste alternatief is om die boek siklies te lees. Dit beteken dat dieselfde inhoude by herhaling aangebied word. Maar 'n sikliese lees kan ook spiraalagtig wees in die sin van siklusse wat herhaal word, maar met steeds intenser inhoude. Vergelyk Desrosiers (2000:5760) vir die alternatiewe.

${ }^{36} \mathrm{Hy}$ voeg Openbaring 19:1-8 as B' by Openbaring 18. Hoewel hierdie verse die gedeelte oor die prostituut verder interpreteer, is dit as oorgangsteks ook 'n voorbereiding op die volgende gedeelte oor die bruid en behoort streng gesproke nie by Openbaring 18 nie. Die formele analise wys ook uit dat dit 'n nuwe deel is.
} 


\subsection{Die ommekeer}

Die raam van die ringkomposisie $\left(A / A^{\prime}\right)^{37}$ fokus op die radikale ${ }^{38}$ en onvoorsiene ondergang van Babilon. In die voorafgaande visioen is die grusame gebeure van sy val vermeld. Die prostituut se meelopers, die dier waarop sy sit en die tien horings, trek haar kaal uit, eet haar vleis en steek haar aan die brand (Op 17:16). Hierdie gebeurtenis word in die kommentaar op die visoen in Openbaring 18 verduidelik en dit gebeur veral in A en $A^{\prime}$.

'n Skets van hierdie raam met sy twee gedeeltes toon die netjiese patroon: Daar is eers ' $n$ netjiese ringskomposisie in $A$.

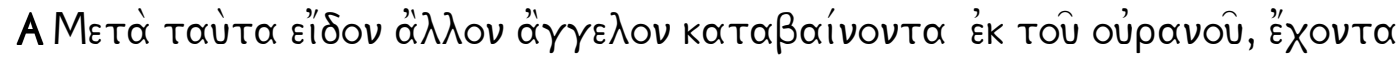

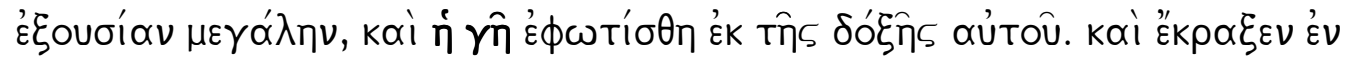

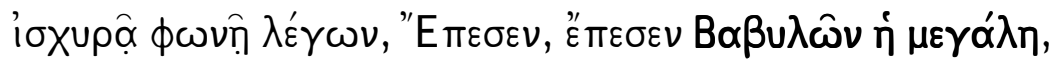

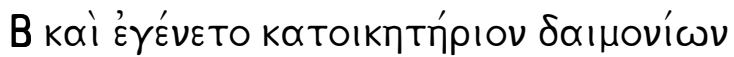

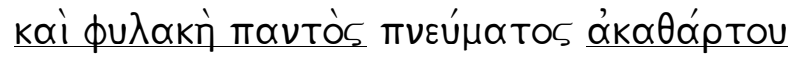

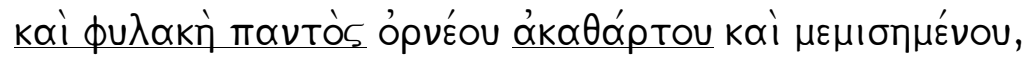

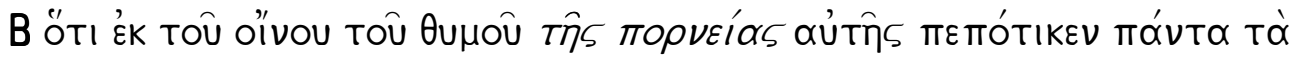
¿ै$\theta \nu \eta$,

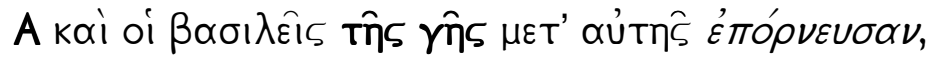

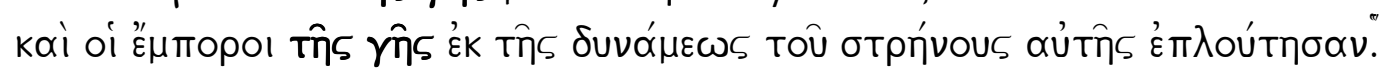

Hier word eers die val dan, tweedens, die aard (die stad word 'n woeste plek van onreinheid) en derdens die driedubele oorsaak van Babilon se ondergang genoem: die nasies en die konings het met haar gehoereer en die handelaars het ryk uit haar geword. Haar "hoerery" as simbool vir afgodery en ekonomiese uitbuiting veroorsaak die val. ${ }^{40}$ Openbaring 17:2 toon hoe belangrik die sake vir Johannes was want hy het dit reeds daar ter sprake

${ }^{37}$ Dat A en A' 'n raam vorm blyk veral uit drie sleutelfrase's van die sterk "engel," die uitdruklike verwysing na "groot Babilon" en "al die nasies" wat net hulle met mekaar deel. Ook die inhoud wys op hulle samehang: Hulle optrede is kosmies, want dit raak hemel, aarde (A) en die see $\left(A^{\prime}\right)$. Vergelyk die teksanalise en die verdere motivering hier onder.

${ }^{38}$ Die radikaliteit kom veral uit in die manier waarop Johannes Jeremia se profesie teen Babilon herinterpreteer en veel sterker uitbeel. Jeremia gooi sy profesie saam met 'n klip in die rivier nadat hy dit gelewer het (Jer 50-1). Kyk Visser (1972:210; bv die profeet word 'n engel, die klip 'n rots en die rivier 'n see).

${ }^{39}$ Die teksanalise aan die einde van hierdie artikel bevat weens ruimte beperkings nie die kleiner patrone wat hier uitgewerk word nie.

\footnotetext{
${ }^{40}$ Fekkes (1994:222) beskryf die handelaars as mense wat Babilon se verleiding van mense om weelde te jaag uitbeeld, maar ook sy sosiale en godsdienstige uitspattighede steun en bevorder.
} 


\section{Die ontmaskering van die bose}

gebring. ${ }^{41}$ Daar word die konings se hoerery en die inwoners van die aarde se dronkenskap aan hoerery ook beskryf. In Openbaring 17:6 word die prostituut met 'n beker vol van "die onreinhede van haar hoerery" gesien. Op haar kop staan "die verborgenheid" geskryf: Sy is die moeder van prostitute en gruwels van die aarde (Op 17:4). Dit is dan waarom God se oordeel oor haar kom.

Ook $A^{\prime}$ as tweede "engel"-perspektief het 'n spesiale karakter:

A Kai ñ๊p

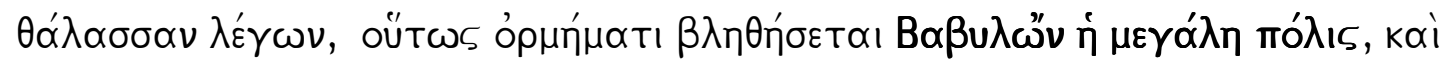

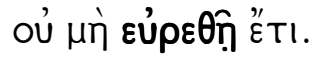

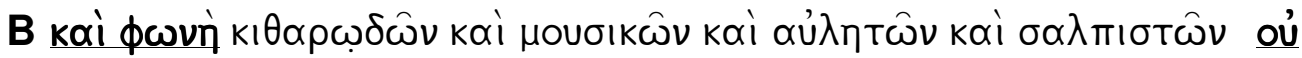

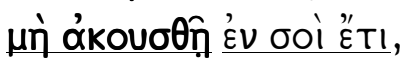

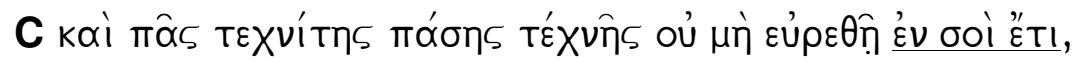

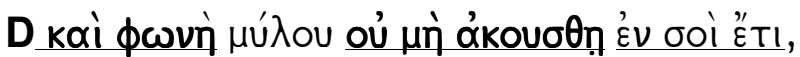

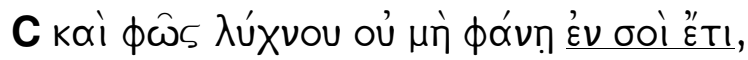

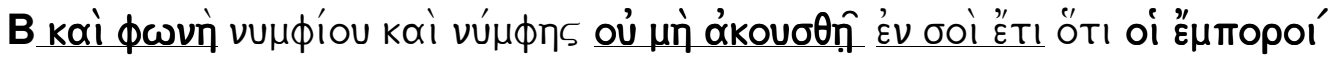

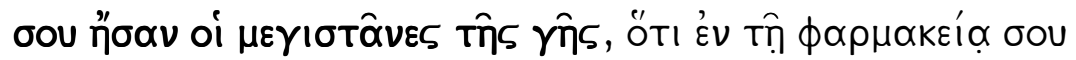

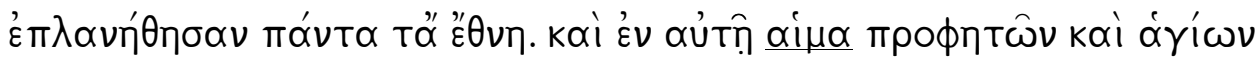

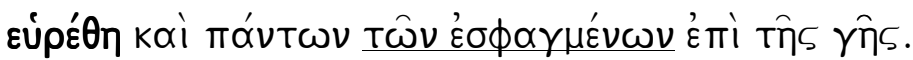

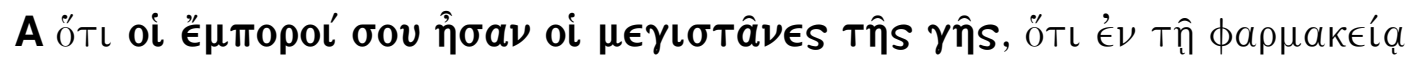

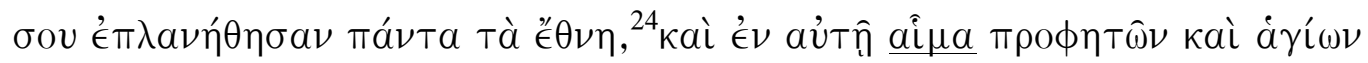

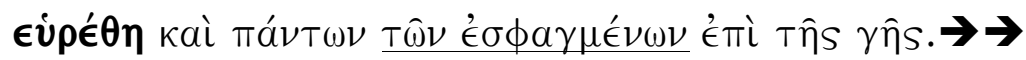

In hierdie kleinere ringskomposisie word soos in A ook eers die val genoem, dan die aard $^{42}$ (die verlies aan spesiale dinge ${ }^{43}$ en derdens die oorsake daarvan. In A val Babilon weens sy verleiding van die nasies deur towery ${ }^{44}$ en weens sy moorde op die volgelinge van God. Maar dit is veral die laaste,

\footnotetext{
${ }^{41}$ Kyk ook Op 21:8 en 22:15. Dit word kortliks weer in die slot hier onder aangeraak.

${ }^{42}$ Let op die logiese verloop in die engel se optel van 'n meulsteen, die gooi daarvan, die "gooi"-toepassing op Babilon met die gevolg daarvan: Babilon sal nie weer gevind word nie. Selfs hier is daar 'n netjiese patroon binne die groter patroon (met die "gooi" wat die middelstuk vorm):
}

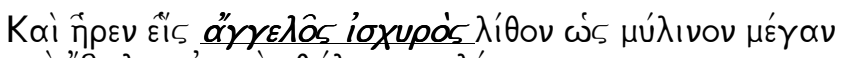

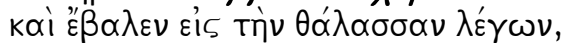

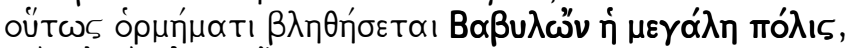

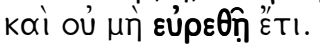

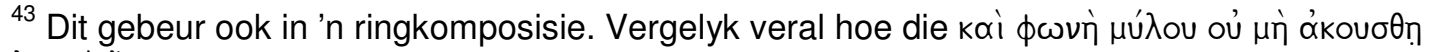

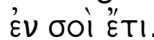

${ }^{44}$ Vergelyk Kraft (1974: 239) vir die verbinding van hoerery en towery veral in Nah 3:4. In die Septuaginta weergawe word die teks ook met die handel verbind. Hoerery en handel word in Jes 23:17 met mekaar geassosieer.
} 
klimaktiese verwysing na die moorde in $A^{\prime}$ wat die aandag trek (Op 18:24). Teenoor Babilon en al die aantreklikhede in haar wat "nie meer gevind word nie" staan die slot-stelling oor die bloed van die profete en heiliges en "geslagtes" wat dan wel in haar gevind word. Ook hierdie opmerking oor die moorddadige aard van die stad was voorheen in Openbaring 17:6 in die inleidende visioen van die prostituut ter sprake. Daardie inleidende verse (Op 17:3-6) eindig ook klimakties met die dubbele verwysing na die prostituut as dronk van die bloed van die heiliges en getuie. Die beskrywing van Babilon se val in die raam $A-A^{\prime}$ eindig ook met sy moorddadige karakter. Babilon, word in die raam van $A^{\prime}$ gesê, is neergegooi en "nie gevind nie" omdat bloed in hom "gevind" is. Die ironie is kompleet: die arrogante stad met al sy aantreklikhede wat in sy keiharde magsgrepe niemand, selfs nie God se getuies, in sy plek duld nie, het van die aarde "verdwyn". Die demoniese en sy bloederige wandade is die enigste oorblywende getuienis van sy bestaan. Sy gewelddadige magsvergrype het uiteindelik sy tol geëis.

Hoewel die driedelige inhoud van die twee rame dieselfde is, is daar nie net blote herhaling tussen hulle nie. Die ringskomposisie onthul 'n klimaktiese, spiraalagtige voorstelling van Babilon se boosheid. Die raam $\left(A / A^{\prime}\right)$ illustreer dus die groot ironiese ommekeer in die lot van Babilon. Babilon die magtige stad op sewe berge wat selfs oor die konings van die aarde regeer (Op 17:18), wat op waters sit wat wêreldvolkere simboliseer (Op 17:15), wat weelderig leef (Op 17:4) en wat op moorddadige wyse absolute mag selfs oor mense se lewens vir hom toeeëien (Op 17:6, maar veral ook Openbaring 13:11-18), het "verdwyn" en is nou 'n onrein woestyn. ${ }^{45}$ Dit is die bitter ironie van Openbaring 18.

\subsubsection{Die hemelse mag}

Die twee karakters wat Johannes in die raam laat optree, is magtige, sterk engele wat met hulle kragtige voorkoms die teenpool uitmaak van Babilon. Die eerste "baie magtige" 46 engel met 'n indrukwekkende voorkoms wat die aarde met sy heerlikheid verlig (Op 18:1), kondig Babilon se val aan. Dit word in $A^{\prime}$ as balanserende element verder uitgewerk deur die simboliese handeling van 'n ander engel. Die engel is ook "sterk". Hy kan 'n klip soos 'n "groot" meulsteen in die see gooi (Op 18:21). Sulke "sterk" engele merk belangrike dele van Openbaring. Hulle kom veral in sleutelgedeeltes in Openbaring voor,

\footnotetext{
${ }^{45}$ Vergelyk Beale (1999:856-9) vir opmerkinge oor die verhouding tussen ekonomie en godsdiens in Op 17-18. Fekkes (1994:222) wys ook op die ekonomiese monopolie, die morele korruptering en die bloedvergieting van die stad as die redes vir sy val. Meer moet egter gemaak word van die bloedvergieting as die klimaks van hierdie rits van elemente om die veelvlakkige ironie tot sy reg te laat kom.

${ }^{46}$ Die onderwerp van mag verdien meer aandag as wat hier daaraan gegee kan word.
} 


\section{Die ontmaskering van die bose}

soos aan die begin van die boek in die troonvisioen (Op 5:2) en in die begin van die middelstuk met die openbaring van die boekrol (Op 10:1). Hulle verteenwoordige God se kragtige handelinge.

Dat, boonop, twee ${ }^{47}$ engele in $A$ en $A^{\prime}$ hierdie vertelling begelei en nie net een soos in die vorige gevalle nie, intensifieer die belangrike draaipunt in die boek verder en verduidelik die val as die magtige oordeelsdaad van God. Boonop is hulle aankondiging oor Babilon sterk - dit word in die sinsinisiële posisie van hulle aankondiging geplaas:

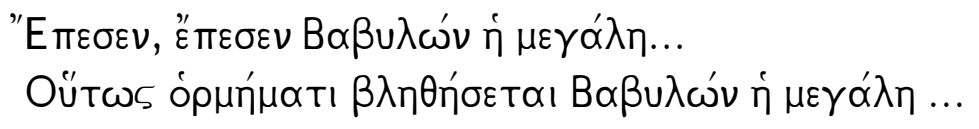

Hierdie frases funksioneer as 'n merker wat wys dat die twee gedeeltes saam gelees moet word. Johannes gebruik hulle in die raam om te wys dat die verhaallyn 'n belangrike wending neem en dat hierdie eenheid binne die verhaallyn afgesluit word.

Hierbo is gemeld hoe die verhaallyn finaal ontknoop as die sterk engele die oordeel oor die prostituut aankondig. Sy (wat laaste van die vier uitgebeeld is) is ook (in 'n chiastiese volgorde) die eerste bose karakter wat van die toneel verwyder word. Johannes teken die stad in die voorafgaande visioen 'n omvattende, komplekse en magtige web van boosheid. Babilon het die siener grootliks verstom gehad (Op 17:6b) want dit het op baie waters gesit het en oor konings van die aarde regeer (Op 17:15, 18). Maar nou word hy neergevel soos 'n meulsteun wat in water gegooi word en verdwyn. Hierdie radikale, verstommende wending is die begin van die einde van die aardse terreur van die bose wat begin het met die val van die draak uit die hemel (Op 12) en oor wie se "woede" die aard- en seebewoners in Openbaring 12:12 gewaarsku is.

Is in Openbaring 17:1 die "oordeel" oor die prostituut belowe en in Openbaring 17:16 voltrek, word die stad se val hier as 'n hemelse magsdaad uitgespel. Die frase in Openbaring 18:1 dat die engel '̌x X $\mu \varepsilon \gamma \alpha^{\prime} \lambda \eta \nu$ laat blyk dat egte mag in die hemel te vind is. Teenoor die gewelddadige magsvergrype van Babilon staan die sterker mag van God. God as Pantokrator (Op 1:8) se mag word nie gestuit deur Babilon nie. Die

\footnotetext{
${ }^{47}$ Caird (1966:230-1) heg baie waarde aan die feit dat die engel in Op 18:21 die derde "sterk" engel is en wil daaruit aflei dat sy verskyning die voleinding van die inhoud van die twee boeke is wat die eerste twee engele gehad het. Maar in die lig van die ringkomposisie is dit 'n probleem, want hierdie engel moet saam met die engel van 18:1 gelees word. Hulle hoort paradigmaties saam. Origens lees Caird (1966:222) nie die engel van Op 18:1 in die lig van die engele in Op 5:2 en 10:1 lees nie. Dit toon aan hoe armer die interpretasie van die hoofstuk is as die ringkomposisie nie herken word nie en as paradigmatiese patrone nie herken word nie.
} 
magtige Babilon staan uitgelewer en magteloos voor hierdie sterk hemelse ingryping. Maar dit is veral die kontras wat opval. Anders as by Babilon, vernietig die hemelse ingryping die bose gewelddadigheid. Dit is die vernietiging van die vernietigers van die aarde wat hier plaasvind (Op 11:18).

In hierdie proses van omkering, neem die gelowiges nie die inisiatief nie. In 'n merkwaardige opmerking het Johannes reeds in Openbaring 17:16 daarop gewys dat Babilon deur die dier vernietig is, maar terselfdertyd ook benadruk dat dit God se bedoeling en wil was (Op 17:17).

\subsubsection{Die plek van onreinheid}

Saam met $A$ as die eerste raam, moet $A$ ' as die tweede en laaste element van die raam gelees word. Daarin verrig die engel 'n simboliese handeling deur 'n meulsteen in die see te gooi en dit met die stad se val te vergelyk (Op 18:2124). Die twee "engel"-perspektiewe gesamentlik 'n geheelbeeld op die aard van Babilon se val. Die aankondiging in A bevat 'n beskrywing van bose en onrein sake wat wel in die stad gevind word (duiwels, geeste, voëls; Op 18:13 ), terwyl A' in kontras hiermee dinge noem wat nie meer daarin gevind sal word nie (stemme, kunstenaar, meul, lig, stem; $\left.{ }^{48} 21-24\right) .{ }^{49}$ In die voorafgaande dele is Babilon hoewel deel van die demoniese, deur die dier en sy meelopers vernietig (Op 17:16). Hier word die stad nou verder met groter intensiteit as blyplek van die demoniese uitgebeeld (Op 18:2). Die besige, magtige stad is nou, paradoksaal genoeg, 'n verlate,

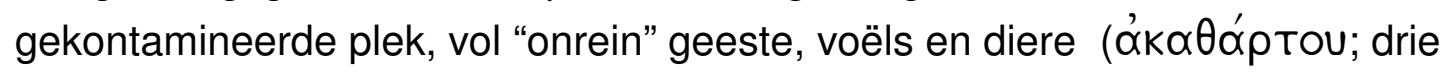
keer herhaal! Op 18:2). Reeds vantevore is vertel dat die prostituut, hoewel pronkend in luukse, 'n goue beker vol "gruwels en onreinheid" in haar hand

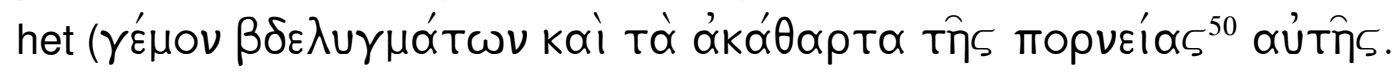
Op 17:4). Die onreinhede in haar beker het nou in haar plek gekom. Dit is, ironies omdat die Nuwe Jerusalem as die teenpool van Babilon 'n plek is waar niks onreins inkom nie ( $\beta \delta^{\prime} \varepsilon \hat{u} u \gamma \mu \alpha ;$ Op $\left.21: 27\right)$.

Dit is 'n dramatiese ommekeer wat vol ironie is: die leser word hier met binnekring-inligting ingewy om hulle situasie van dreigende geweld te sien vanuit die toekomstige val van die stad.

\footnotetext{
${ }^{48}$ Prigent (2001:513) dink "the author speaks with a poetry that is full of tenderness for these modest but inviting traces of life, of joy, and of human activity" wanneer hy hierdie elemente opnoem. Beale 1999:920 glo weer dat hier verwys word na "the pleasures of an affluent society."

${ }^{49}$ Fekkes (1994:217) het 'n aanvoeling vir hierdie kombinasie want hy praat van 'n "sort of chiastic parallel van hierdie gedeeltes. Tog ontwikkel hy dit nie verder nie.

${ }^{50}$ Hierdie woord is belangrik in Openbaring. Dit word in 2:14, 20, 21 (2x); 9:21; 14:8; 17:2, 4, $5,18: 3,9$ en 19:2 gebruik. Dit wys nie letterlik op hoerery nie, maar op afgodery. Babilon is so verwerplik omdat hy vir homself goddelike eer toeëien (Op 17:3).
} 


\subsubsection{Die oorsake}

Die raam van Openbaring 18 bied 'n multidimensionele voorstelling van boosheid. Verskeie groepe en praktyke, vanaf die politieke en ekonomiese maghebbers tot by die wêreldnasies word vir hulle immorele ekonomiese uitbuiting, godsdienstige arrogansie (hoerery), towery, maar veral moord op profete en heiliges veroordeel. Op die agtergrond van hierdie gedeelte funksioneer magsvergryping wat sy skaduwee oor al die aktitwiteit van die stad laat val. Die ekonomiese verryking van die handelaars kom deur "die

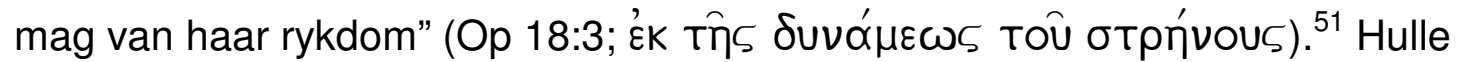
handel met die stad maak hulle so ryk (Op 18:15) dat hulle die "magtiges /

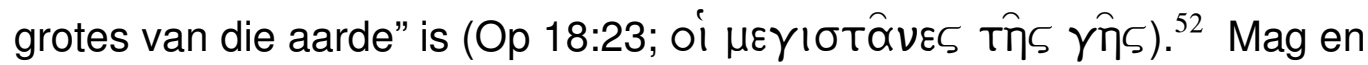
gewelddadige magsvergrype kenmerk die stad en is die oorsaak van sy ondergang.

Die beste voorbeeld van die stad se gewelddadigheid wat die oorsaak vir sy val is, blyk uit Openbaring 18:13 oor slawe en mensesiele wat Bauckham (1993:371) interpreteer as 'n kommentaar op die lang lys van goedere wat daaraan voorafgaan. "It suggests the inhuman brutality, the contempt for human life, on which the whole of Rome's prosperity and luxury rests." Dit is nie die enigste verwysing na die minagting vir menselewens nie. Die hemelse oordeel kom ook volgens Openbaring 18:24 oor Babilon vanweë die verspilling van gelowiges en van almal wat op aarde gedood is se bloed (Op 18:24). Die geweld van Babilon bereik sy dieptepunt in sy totale onverskilligheid teenoor ander mense.

Hierdie ommekeer tref Babilon as 'n magsdronk moordenaar wat op 'n arrogante manier die wêreld deur die mag van sy weelde en deur sy ongebreidelde geweld vernietig. Soos die samevattende beskrywing van

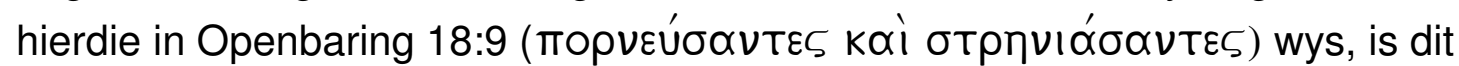
haar afgodery en weelde wat as 'n goue draad hierdie gedeelte saambind. Babilon dwing deur geweld sy absolute aansprake op die wêreld af. Dit is dus wesenlik 'n godslasterlike plek, deurtrek met laster - vandaar dat dit vol lasterlike name is (Op 17:3; 13:15; kyk ook verder hier onder). Geweld is dus

\footnotetext{
${ }^{51}$ Aune (1998:990) dink dat Op 18 nie handel oor ekonomiese uitbuiting nie. Maar kyk Bauckham (1993:338-383). Beckwith (1922:713) het reeds verwys na die weelde van Rome "as an actual power, which has worked to the enrichment of the traders." Maar dit is Beale (1999:894) wat die mees bevredigende insig bied. Hy lees die frase oor die "mag van haar rykdom" nie as 'n deskriptiewe genitief (weelderige mag) nie, maar as 'n genitief van bron, d.w.s. as mag wat van rykdom kom. Hy lees dit as 'n sinspeling op Eseg 27:12.

52 Vergelyk Fekkes (1994:221-2); Kraft (1974:239) en Giesen (1997:405) vir die OuTestamentiese agtergrond van die uitdrukking in Jer 27:35; 32:15-7 en 23:9, maar veral ook Eseg 27.
} 
'n fundamentele beskrywingskategorie vir die stad. Die val van die stad word daardeur veral verbind met gewelddadigheid.

Johannes wys voorts ook deur die verdere opbou van die gedeelte op die gevolge van die val en doen dit vanuit twee perspektiewe. Dit vra nadere aandag.

\subsection{Die stad vanuit menslike perspektief}

Uit bogenoemde bespreking blyk hoedat die raam ( $A$ en $A^{\prime}$ ) aan die lesers die aard en gevolge vir Babilon se val verduidelik. In die middelstuk van die ringskomposisie (C/D / en C'/D') gee Johannes nou deur Babilon se politieke en ekonomiese meelopers 'n perspektief op die gevolge van die stad se ondergang (Op 18:9-19). Die patrone in hierdie middelstuk wat hulle reaksie goed illustreer, kan weens beperkte ruimte nie hier uitgewerk word nie, maar word blyk duidelik uit die aangehegde analise. Verskeie motiewe in die toesprake van die meelopers kom net in hierdie twee dele van die middelstuk voor en wys dus op hulle koherensie. Terselfdertyd onderskei hierdie motiewe die gedeeltes duidelik van $A$ en $A^{\prime}$.

Johannes se bedrewenheid blyk ook wanneer hy in hierdie gedeelte 'n lokliseringsmotief gebruik om 'n perspektief op die verhaallyn uit te werk. Deur

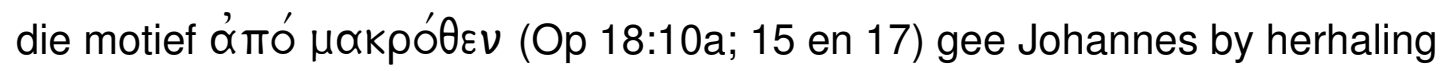
in elke gedeelte 'n aanduiding dat hy 'n buitestaander se perspektief op die stad se val wil aanbied (Aune 1998:997). Die lesers word daardeur gestimuleer om hulle in te leef in die reaksie van mense wat as meelopers die ondergang van die stad beleef en wat nou "van buite" af hierdie gevalle stad staan en bekyk. Johannes skep 'n paar groepe, weer eens om 'n multidimensionele buite-perspektief te ontwikkel. Boonop doen hy dit op meesleurende, byna misleidende manier. Die emosies van die konings, die handelaars en verskillende groep seelui word intens dramaties uitgebeeld.

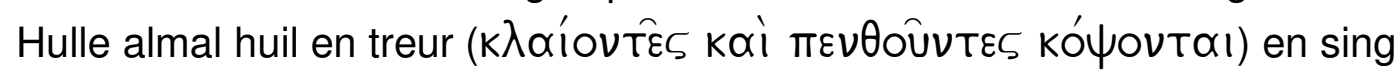
dan drie trenodes. Die seelui gooi selfs, in simboliese handeling van rou, stof op hulle koppe.

In hierdie middelstuk, wat hoofsaaklik op die handelsvennote van die stad fokus, word ook ander motiewe ingewerk. In $\mathrm{C}$ is byvoorbeeld politieke mag ter sprake. Die konings as magshebbers treur gepas oor die "sterk" stad (Op 18:10). Maar selfs in hulle geval word hulle jag na weelde bygevoeg as 'n

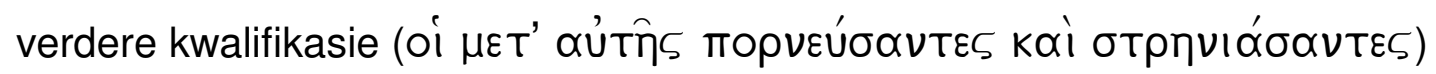
sodat die assosiasie met die ekonomiese aspek reeds hier duidelik is.

Behalwe vir die konings, is daar verwysings na die seelui ( $\mathrm{C}$ en $\mathrm{C}^{\prime}$; vgl Op 18:3, 9-10), maar dit is veral die handelaars wat sterk in fokus is (D/D') Hulle word ten minste vier keer genoem (Op 18:3, 11, 15, 23). Soos die 


\section{Die ontmaskering van die bose}

konings het hulle ook buitengewone mag. Die handel met die stad maak hulle so ryk (Op 18:15; kyk 18:3) dat hulle die "magtiges/grotes van die aarde" is (Op 18:23). Hoe groot hulle mag is, blyk uit die vraggoed van veral weelde artikels wat hulle karwei. Soos hierbo aangetoon is selfs mense deel van hulle

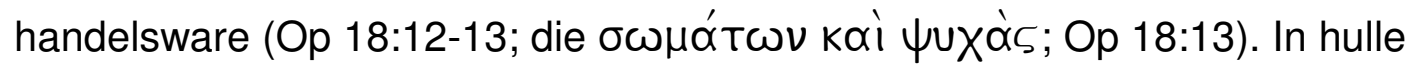
beskikking oor menselewens kom hulle absolute mag na vore.

Die hewige, negatiewe reaksie van hierdie drie groepe meelopers spel nou op 'n ironiese manier die verreikende gevolge van Babilon se val uit. Sy val affekteer hulle lewensomstandighede ingrypend. Hulle wat vroeër magtige meelopers was en in die hart van al die besige aktiwiteite gestaan het, moet nou, ironies, 'n veilige afstand inneem terwyl rook uit die stad opgaan (Op $18: 10,15,17)$. Hulle wat voorheen uitbundig vrolike musiek geniet het (Op 18:22), treur en rou in ontsteltenis, vol vrees oor wat haar oorkom (Op 18:10;

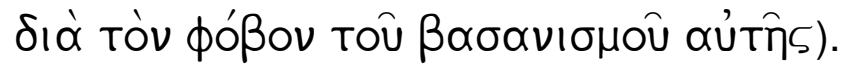

Maar van belang is dat die ironie tweedens ook op 'n dieper, religieuse vlak werk. Ten spyte daarvan dat hulle die val en "krisis" van Babilon meemaak (Op 18:10), bring sy ondergang hulle nie tot 'n werklike insig in sy gewelddadige identiteit nie. Hulle kom nie tot inkeer nie. Hulle bly onberoulik in hulle verbintenis aan Babilon. Selfs na haar val, vra hulle dus nog verlangend: "watter stad is soos die groot stad?" (Op 18:18). Hulle houding bevestig Openbaring 9:20-21 waar die sewe trompette met hulle verskriklike oordeel ook nie tot berou lei nie. Daar aanbid die mensdom nog duiwels en afgode, terwyl hulle ook hulle moorde, towery, hoerery en diefstalle nie opgee nie. Geweld is endemies en so in die menslike leefstyl ingebed, dat selfs die rampe van die eindtyd dit nie altyd tot 'n einde kan bring nie. Giblin (1991:103) merk op: "Much is suggestively disclosed if one follows the progressions of John's sedulously articulated septenaries and sequences of visions ....

Repentance is constantly urged, but not forced; for pagans, matters pass from bad to worse, though not necessarily so. The mystery of evil lies in human obstinacy."

In die teks word egter meer gesuggereer as net dat die geheim van die bose in menslike verharding en onbekeerlikheid te vinde is, soos Giblin hier skryf. Uiteindelik wys die onbekeerlikheid op die onverskilligheid teenoor die Ander en 'n obsessiewe self-verheerliking (kyk verder hier onder). Dit is 'n houding wat sterk kontrasteer met die gelowiges wat in Openbaring 15:4 die lied van die Lam sing: "Wie sal U nie vrees nie? $U$ alleen is heilig!" Wat werklik op die spel is, blyk daaruit dat die enigste vraag wat die seelui vra is "watter stad is soos hierdie groot stad?" (Op 18:18). Hulle visie is tot die stad beperk. Die stad verteenwoordig vir hulle die ultieme waarde. 
Vanuit die perspektief van die luisterende gehoor en Johannes se volgelinge is die effek van die gedeelte dubbel ironies. Behalwe vir die ironiese ommekeer in die verhaal, word hulle deur die teks bemagtig om met ander oë te kyk na hulle korrupte magshebbers met al hulle hoë aansprake en hulle volhardende onberoulikheid. Dié wat nou mag het, is die roubeklaers van die toekoms. Die rook van 'n brandende Babilon in $C$ en $C$ ' hang vir hulle nou al heel plasties oor die weelderige lewensstyl van Babilon as simbool van hulle eie opponente. Hulle beleef die komende oordeel so intens, dat dit vir hulle nou reeds finaal is en Babilon se val in die verlede geplaas word. ${ }^{53}$ Johannes se luisteraars word dus met hierdie menslike perspektief op Babilon se val gestel juis om die dieper insig te ontwikkel dat hulle ánders moet dink. Hulle moet nie in die strik trap om soos die meelopers te reageer nie. Met ander woorde, ten diepste vertel hierdie middelstuk hoe 'n mens nié op die verleidinge van 'n wêreldstad, van magtige weelderigheid, moet reageer nie.

\subsection{Die hemelse perspektief}

Johannes bied voorts 'n tweede, radikaal teenoorgestelde perspektief op die val van Babilon. Hy omraam die menslike perspektief (in $C / D$ ) met 'n hemelse siening van die gebeure in B en B'. In die eerste deel (B; Op 18:4-8) word "my volk" opgeroep om hulle van Babilon te distansieer, terwyl B' (Op 18:20) die hemel, heiliges, apostels en profete tot vreugde oproep. ${ }^{54}$ Die analise hier onder toon dat die binneraam (B en B') ook unieke motiewe met mekaar deel wat bewys dat hulle 'n eenheid vorm en dat hulle as parallele gedeeltes gekonsipieer is. Die gedeelde motiewe behels parallelle imperatiewe (Op 18:4

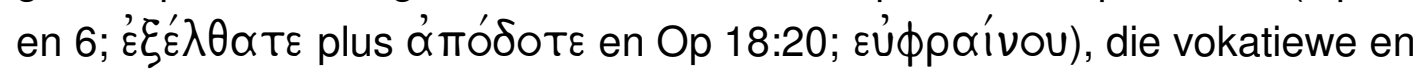
die motief van oordeel. Boonop vorm albei gedeeltes die inhoud van die hemelse stem wat in Openbaring 18:4 aan die woord kom. ${ }^{55}$ Seker is wel dat die gedeelte 'n goddelike perspektief op die val wil gee.

\footnotetext{
${ }^{53}$ Boesak (1987:119) skryf, "We must remember that as John writes there is no sign whatsoever of the imminent fall of Rome. He speaks like an Old Testament prophet. The vision is so clear, God's decision is so certain, that for all intents and purposes it has already happened."

${ }^{54}$ Hierbo is die bedenkinge in die debat oor die plek van vers 20 in die hoofstuk bespreek. Nie net word vers 20 met sy opdrag tot eenheid vanuit die perspektief van 'n ringskomposisie 'n koherente deel van die hele gedeelte nie, maar dit pas ook uitstekend in as teenpool vir B. Die negatiewe reaksie van distansiëring word gekontrasteer met die positiewe aksie van vreugde. Dit bevestig net sterker dat die vers nie as 'n gedislokaliseerde teks beskou kan word nie.

${ }^{55}$ Die debat of die woorde uit die mond van Christus of God kom kan nie finaal na een of ander kant beslis word nie. Vergelyk Aune (1998:990-1) vir literatuur. Die probleem is dat Op 18:4 praat van "my volk," maar in Op 18:5 word na God in die derde persoon verwys.
} 
Dit is opvallend dat albei B en B' die val van Babilon in terme van God se oordeel sien.$^{56}$ Dit is 'n belangrike perspektief, veral omdat Babilon in Openbaring 17:16-7 deur die dier en sy horings haar ondergang veroorsaak het. Die feit dat daar in Openbaring 18 soveel klem op God se oordeel gelê word, moet egter nie misverstaan word nie. Die lang oproep tot vergelding in $B$ en die baie kort B' met sy opdrag tot vreugde moet binne konteks van die verhaallyn gelees word. $\mathrm{B}^{\prime}$ is wel kort, maar dit is omdat dit net die groter, durende vreugde in Openbaring 19:7 voorberei wat die beskrywing van die Nuwe Jerusalem begelei. In Openbaring 18:20 handel die vreugde oor die oordeel en die verdwyning van die bose stad, oor dit wat plek moet maak vir die groter, belangriker heilstyd. In Openbaring 19:7 word hierdie vreugde opgevolg deur vreugde oor die koms van die bruid as die aanduiding van die komende heilstyd. Die heilsvreugde oor die nuwe bedeling wat die einde van Openbaring invul, oorheers uiteindelik die blydskap oor die vernietiging van die bose en die verbygaan van die ou bedeling met al sy geweld. Trouens, uit die parallelle plasing van die prostituut en die Nuwe Jerusalem blyk dit dat die oordeel in diens staan van die groter vreugde oor heil, want dit is per slot van sake waarop alles afstuur. Die oordeel oor Babilon word getemper en uiteindelik gerelativeer deur die heil. Daarmee word die bose stad gekwalifiseer as die instabiele, die afwykende, wat die heil in die plek staan en die nuwe skepping van God terughou.

Hier moet egter spesiale aandag gegee word aan $B$, veral omdat dit teen die verloop van die boek skynbaar van gelowiges 'n onverdraagsame, selfs gewelddadige optrede vra. Ook Hierdie oproep tot vergelding word in netjiese kleiner patrone verdeel.

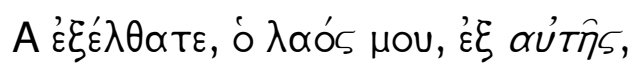

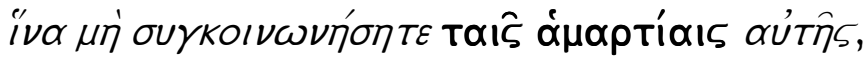

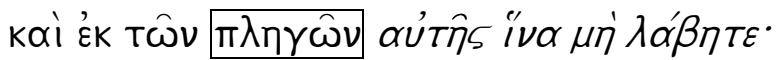

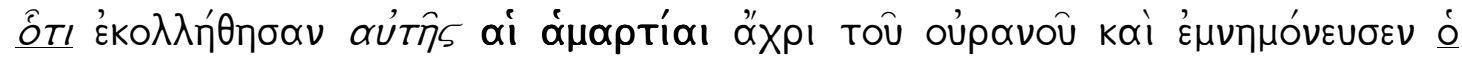

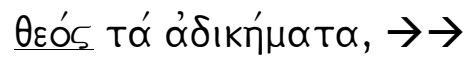

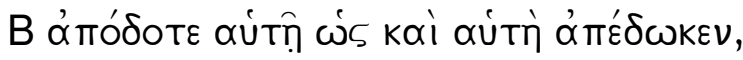

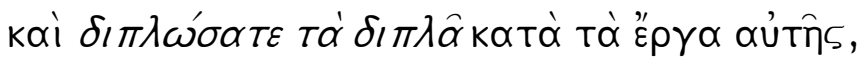

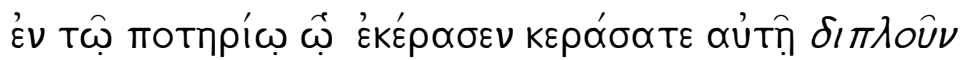

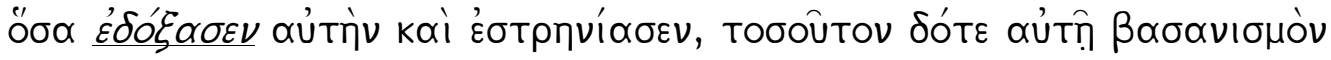

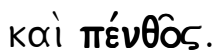

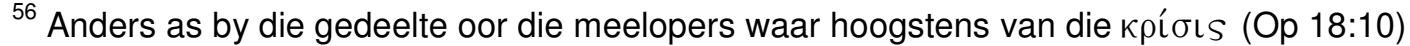
van Babilon sprake is, word in hierdie gedeelte die val van die stad herken as 'n gevolg van

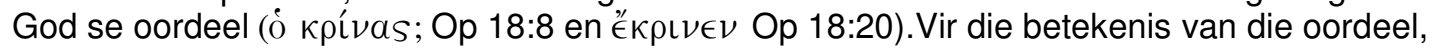
kyk die belangrike opmerkings van Fekkes (1994:224-5). Volgens hom wys dit op die regsproses waarin oordeel gevel word en die strafmaatreëls wat daaruit voortsproei.
} 


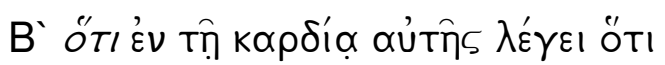

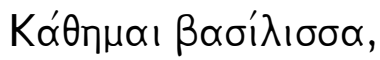

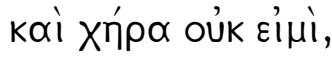

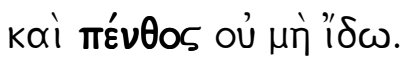

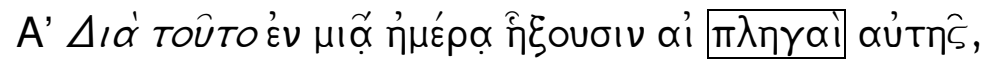

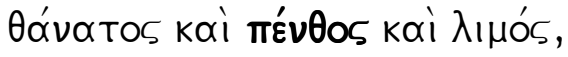

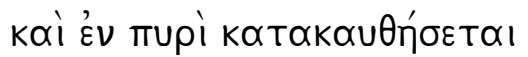

ötı íxupòs kúpıos ò $\theta$ zòs ó kpívas aủtrív. $\rightarrow \rightarrow$

Elkeen van hierdie gedeeltes ontsluit aspekte van die betekenis van Babilon se val en elkeen het 'n eie interne struktuur. In die eerste afdeling word die volk gevra om hulle van Babilon se hemelhoë sonde te distansieer, in die tweede afdeling word hulle gevra om die stad dubbel te vergeld weens haar self-verheerliking, gevolg, derdens, deur 'n beskrywing van die stad se aansprake en die gevolge daarvan. Dit is opvallend dat die plae- en droefheidmotiewe sterk aanwesig is in die gedeeltes. Plae word in $A$ en $A^{\prime}$ genoem. Die vierde deel ( $\left.A^{\prime}\right)$ voeg by die plae nog droefheid wat in $B$ en $B 1$ voorkom. $A^{\prime}$ vloei dus voort uit $A, B$ en $B^{\prime}$. Vanuit die perspektief van die plae en droefheid is die verloop van die vier dele as volg: Die volk moet haar plae vermy $(A)$, haar dubbel vergeld met droefheid $(B)$, want sy het haarself as sonder droefheid beskou ( $\left.B^{\prime}\right)$. Daarom sal plae en droefheid (plus ander dinge) oor die stad kom, want die Here oordeel haar (A'). Hier word dus die volk se reaksie op die plae en die droefheid wat dit meebring, uitgespel. Binne hierdie vier dele staan die volgende twee aksies van die volk nou uit:

\subsubsection{Afstand van boosheid}

Dit is reeds uitgewys in die bespreking van die middestuk dat die meelopers van Babilon ' $n$ veilige afstand van Babilon bewaar, maar sonder dat hulle Babilon se egte karakter en identiteit herken. Hierteenoor roep die eerste imperatief (Op 18:4-5) in B/B' die volk van God op om hulle te onttrek van die stad. Die motivering is duidelik. Hulle hou afstand om nie besmet te raak met sy sondes nie. De sonde van die stad word by herhaling uitdruklik genoem wat verklaar waarom haar val ook as God se oordeel geïnterpreteer word. Daar is dus niks willekeurigs omtrent die ondergang van Babilon nie. Die klimaktiese laaste reël van vers 5 onderstreep hoe groot die stad se boosheid is deur sy "sonde" wat twee keer genoem word, met "ongeregtighede" (Tó $\left.\alpha \dot{\delta} ı \imath_{n} \mu \alpha \tau \alpha\right)$ te verbind en deur die frase dat Babilon se sonde "tot aan die hemel" gereik het. Hierdie hiperboliese uitdrukking wat sinspeel op Jeremia 51:9 en Esra 9:6, dui op sonde wat só 'n omvang aanneem dat dit die 


\section{Die ontmaskering van die bose}

soewereiniteit van God aantas deur tot by die hemelse sfeer voort te dring. ${ }^{57}$ Ook dat God die stad se ongeregtighede "onthou" illustreer die stad se boosheid. Vir Johannes is dit 'n belangrike motief wat ten nouste saamhang met die prominente oordeelsmotief elders in die gedeelte. In Openbaring 16:19 skryf hy hoe God Babilon die Grote "onthou" met die voltrekking van die oordeel. Intertekstuele lyne bevestig dat God in Ou-Testamentiese tekste die boosheid van Israel se vyande "onthou" as 'n teken van oordeel en as 'n rede om dit te wreek (Ps 25:7; 137:7; vgl Aune 1998:992). Babilon is 'n stad wat onder oordeel staan. Die korrupsie en die geweld van die stad verteenwoordig 'n lewenssfeer waaraan hulle geen deel kan hê nie. ${ }^{58}$

Om hierdie rede moet hulle uit die stad padgee. ${ }^{59}$ Hulle moet ten alle koste geen deel aan die stad se onreinheid hê nie, want dit sou beteken dat hulle geen deel aan die Nuwe Jerusalem sal kry nie (Op 21:27; Beale 1999:899; Roloff 1987:175; Prigent 2001:504; Aune 1998:1012). Die effek van hierdie hemelse oproep is dat hulle as "volk" gered word deur nog 'n uittog. "John wants his audience to configure itself as Israel being rescued by Yahweh from exile ..." (Maier 2002:186). Hulle word uitgelei terwyl Babilon deur plae oorval word. Daarom wys die hemelse oproep om uit die stad te kom, eintlik op 'n heilsgebeure en op bevryding uit 'n situasie van gewelddadigheid.

Die ironie in die situasie van die lesers is duidelik: die lesers word ingelig dat terwyl mense tans hulle heil in die stad vind, daar 'n tyd sal kom dat hulle in radeloosheid buite die stad sal staan. Dit sal die oomblik van bevryding wees wanneer die nuwe volk van God deel sal hê in die nuwe eskatologiese uittog uit die stad.

\footnotetext{
${ }^{57}$ Aune (1998:992), met verwysing na Houtman. Vergelyk ook in herdie verband soorgelyke opmerkings van Giesen (1997:394).

${ }^{58}$ Aune (1998:1012; vgl 1991) se voorstel dat dit bloot gaan om 'n oproep om die versoekinge van die Grieks-Romeinse kultuur te weerstaan water die intensiteit van die korrupsie en geweld van Babilon te veel af.

${ }^{59}$ Die opdrag aan die volk om te vlug uit "die stad" kan nie letterlik verstaan word, want dit word immers gegee aan Asiatiese Christene in sewe stede en nie aan lesers in "die" stad Rome nie (Mounce 1977:324; Boring 1989:189; Müller 1995:303; Aune 1998:991). Dikwels word ontken dat gelowiges tot wraak opgeroep word omdat die "my volk" in Op 18:4 nie verduidelik word nie. Dit kan nie die "volk van God" wees nie omdat die spreker nie God is nie, maar 'n "ander stem uit die hemel" (Mounce 1977:324). Of dit word geargumenteer dat nie die gelowiges self nie, maar die dier en die horings die instrumente van wraak is wat volgens Op 17:16 die stad tot niet maak (Bousset 1906:420; Beasley-Murray 1974:265; Swete 1911:229; Van Hartingsveld 1985:75; vgl Caird 1966:224). Of die weerwraak word as minder problematies beskou omdat dit teen die staat en nie teen 'n persoon gerig is nie (Beckwith 1919:723-4). Prigent (2001:504) argumenteer dat die wysiging van subjek in vers 6 daarop dui dat die Christene instrumente van straf eerder as bewerkers van vergelding is. Die opdrag is dus aan "instruments of punishment to fulfill their function" (Prigent 2001:504). Al hierdie pogings gee nie ruimte vir die intense ironie van die gedeelte nie.
} 


\subsubsection{Dubbele vergelding}

Problematies is die skynbaar wraaksugtige opdrag tot vergelding in Openbaring 18:6-7 omdat dit lyk of gelowiges hier opgeroep word tot wraakgierigheid. Ook hier is die taal besonder intens wanneer die skrywer met vier imperatiewe vra dat Babilon in dubbele mate vergeld moet word. Dit is 'n moeilike kwessie wat 'n veelkantige benadering vra.

\subsubsection{Geen wraakgierige vernietiging nie}

Reeds die inherente spanning tussen die oproepe tot "distansiëring" en "vergelding" moet egter al 'n aanduiding gee dat hierdie gedeelte ironies opgeneem moet word. As uitgangspunte vir'n verklaring moet die volgende hier geld. Die eerste imperatief om uit die stad te kom, was 'n oproep tot afwysing van enige gemeenskap met die kwaad en sekerlik nie 'n konkrete wegvlug uit die stad nie. Die daaropvolgende oproep om te vergeld sou dus moeilik letterlik verstaan kan word asof Christene die wapen moet opneem teen die stad uit weerwraak vir wat hulle aangedoen is nie. 'n Tweede vertrekpunt is dat die gedeelte veronderstel dat die stad reeds vernietig is (Op 17:16). Die gelowiges se dubbele vergelding bring nie die stad tot val nie. Haar val kom deur die dier en sy meelopers. Die val van die bose is in die bose leefstyl self ingebed (Op 17:16). Die dubbele vergelding verwys dus nie na die gelowiges se uitwissing van die stad nie.

\subsubsection{Dubbele vergelding?}

Al sou die vergelding deur Babilon se gewelddadigheid gemotiveer word, bly die motief van "dubbele" vergelding oordrewe en hard. In een van die pogings om die impak van hierdie gedeelte te versag, wys Beale (1999:901) die lesing "dubbel" of "in dubbele maat" af en beweer dat dit eerder dui op herhaal of dupliseer. ${ }^{60}$ Dit sou beteken dat die stad die ekwivalent van haar eie optrede moet ontvang. Maar die sentrum van die gedeelte vra twee keer 'n dubbele vergelding. Die volgende patroon wys hoe Johannes die dubbele vergelding fokaliseer in die inisiële en finale posisies van die sinne.

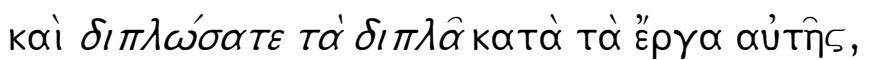

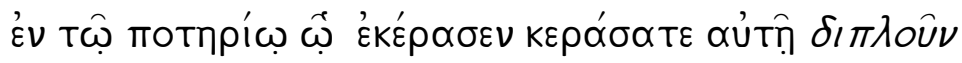

Dat Johannes wel "dubbele" vergelding vergelding bedoel het en nie "gepaste" vergelding nie, blyk daaruit dat hy gevestigde profetiese tradisies oor dubbele vergelding oorneem (vgl Jer 16:18; 17:18; Jes 40:2; Kraft

\footnotetext{
${ }^{60}$ Vergelyk ook Beckwith (1922:715) wat dit in soortgelyke sin kyk as "full requital" eerder as dubbele vergelding.
} 


\section{Die ontmaskering van die bose}

1974:230; Lohmeyer 1953:149). Die profetiese tradisies word vervul: God gedenk onreg en roei dit wortel en tak uit. Johannes gebruik tradisionele vergeldingstaal in hierdie agonistiese teks om sy lesers aan te moedig "to understand the world in terms of older patterns. Clearly he wants his audience to hear him as representing the voice of a time-honored sacred past, and his opponents as innovators representing inferior characters" (Maier 2002:106). ${ }^{61}$ Wanneer Johannes sy gehoor oproep tot vergelding, doen hy dit met OuTestamentiese gevestigde, stereotiepe taal (Roloff 1984:176) waardeur hy hulle herinner aan hulle verantwoordelikheid tot 'n heilige lewensstyl. Hier word die gelowiges opgeroep om dubbel en dwars die gewelddadigheid van Babilon af te sweer en ook maar geen aandeel hoegenaamd daaraan te hê nie.

\subsubsection{3 'n Morele vergelding}

Die oproep tot vergelding moet ook verbind word met die oordeel van God wat in Openbaring 17:17 uitgespel word en wat aan die werk is in die vernietiging van die Bose deur die dier en sy meelopers. ${ }^{62}$ In Openbaring 18 word daardie oordeel van God verbind verder verbind met die gelowiges se veroordeling. Met hierdie opdrag kry die gelowiges deel aan God se oordeel oor die stad. Die mede-regterskap van gelowiges is nie vreemd aan Openbaring nie. Hulle medeseggenskap word elders duidelik uitspel (Op 20:4).

Behalwe dat die stad se sonde die reaksie van die gelowiges motiveer en die oordeel of vergelding dus nie willekeurig is nie, vind die vergelding ook, soos die gedeelte eksplisiet sê, volgens die stad se werke plaas (Op 18:6). Maar selfs in hierdie intense, ironiese taal is die vergelding nie ongebreideld nie. ${ }^{63}$ Die stad moet steeds "volgens sy werke" geoordeel word. Hier gaan dit om 'n gepaste oordeel by 'n gepaste oortreding. Dit is in lyn met Openbaring 2:23 waarvolgens God elkeen volgens werke gee en Openbaring enbaring en Openbaring 19:8 waar die bruid van die Lam versier is met die regverdige dade van die gelowiges (Giesen 1997:394). Babilon se werke regverdig 'n dubbele oordeel oor haar. Dit is veral die geval omdat dit so diep lasterlik is soos nou verduidelik moet word.

\footnotetext{
${ }^{61}$ Vergelyk ook Maier (2002:187) waar hy waarsku dat die verwysings na oorlog en geweld nie letterlik verstaan moet word nie. Hy gebruik stereotiepe taal wat in die konteks van sy werk aangepas en gedekonstrueer word.

${ }^{62}$ Op 18 beklemtoon dat God die stad oordeel (Op 18:8, ook 20 en nog sterker in Op 19:1-3; vgl Fekkes 1994:211).

${ }^{63}$ Johannes teken hier nie haat nie soos by tye in Qumran dokumente gevind word nie (cf
Hasel 1995:631).
} 


\subsubsection{Lasterlike arrogansie}

Die oproep tot dubbele vergelding moet verstaan word teen die agtergrond van die klimaktiese reël in die tweede komponent (Op 18:6-7a) waar verwys

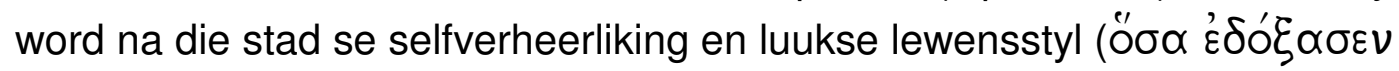

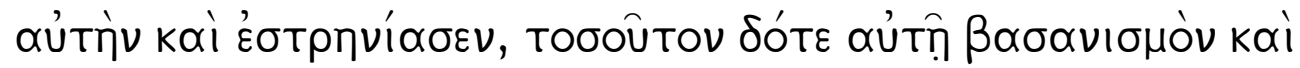

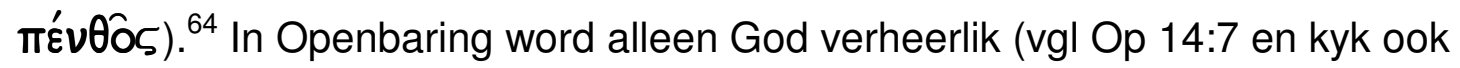
15:4). Self-verheerliking is in die profetiese literatuur van Babilon as lasterlik beskou. ${ }^{65}$ Die vorige verwysing na die omvang van Babilon se sonde en ongeregtighede word deur hierdie motief van self-verheerliking verder uitgebou om haar lasterlike optrede te beklemtoon. Die derde komponent (Op 18:7b) intensifieer dit alles nog verder: in haar selfversekerdheid en arrogansie maak die stad aanspraak op 'n ewige, durende koninklike magsposisie en dat sy "nooit" droefheid sal kyk nie ("Ek sit as koningin, en is geen weduwee nie, en droefheid sal ek nooit kyk nie").

Hierdie self-verheerlikende en dus self-vergoddelikende taal van Babilon word in die res van die gedeelte geïroniseer. Die stad wat homself beskryf as koningin wat nooit soos 'n weduwee sal treur nie (Op 18:7), sal "op een dag" met droefheid oorval word (Op 18:8). Hierdie frase word opgevolg deur die driedubbele herhaling dat die val "in een uur" gekom het (Op 18:10, $17,19)$ en, met groeiende intensiteit, dat dit permanent sal wees (Op 18:14). Die magtige stad wat wêreldvolkere betower het en wat onder die salige indruk leef van sy ewige status as "koningin", word oornag 'n verlate "woestyn," gestroop van glorie en luukses. ${ }^{66}$ Sy aanspraak dat hy nie droefheid sal kyk nie word ironies teengespreek met die driedubbele opmerking dat sy "dood", "droefheid" en "hongersnood" sal beleef. Dit word deur die volgende klaaglied verder geïroniseer. Babilon se ondersteuners treur bitterlik oor haar val. Teenoor hulle onkunde staan, ironies, die vreugde van die heiliges wat haar val toejuig omdat hulle begryp dit is die einde van 'n gevaarlike moordenaar en lasteraar (Op 18:20; vgl bv Royalty 1998:203). Teenoor Babilon se plae van dood, droefheid en honger (Op 18:8) staan die Nuwe Jerusalem waar God woon en mense nie treur of sterf nie (Op 21:4:

\footnotetext{
${ }^{64}$ Giesen (1997:394) verbind hierdie uitspraak van Babilon tereg met Jes 47:7-8 en 14:13-4, maar vergelyk dit nie met Op se gebruik van die begrip verheerliking slegs i.v.m. God nie. Vergelyk hierteenoor Fekkes (1994:221) se raker opmerking: "The formal charges add up to political absolutism and blasphemous presumption." Vir die motief van eer gee aan God, kyk Aune (1998:994). Volgens Bauckham (1993:344) kom Babilon deur haar uitspraak dat sy 'n koningin is en nie 'n weduwee nie, na aan self-vergoddeliking. Hy verwys nie nie na die selfverheerliking nie - wat duidelik wys op self-vergoddeliking. Kyk verder hieronder.

${ }^{65}$ Byvoorbeeld Deut 32:2; Jos 7:19; Jes 42:8; Jer 13:16; 50:15; 21:42, 56 en 51:45; vergelyk verder 2 Bar 2:1-2; Mk 13:14 en parallelle. Kyk ook Aune (1998:994-5).

${ }^{66}$ Later word haar aansprake selfs nog meer ironies. Sy kon wel die heiliges doodmaak (Op 17:6), maar uiteindelik ontvang hulle die eerste opstanding en sal hulle die bruid van die Lam wees by wie God altyd bly en vir wie God vir ewig troos (Op 20:4-5; 21:3-4).
} 


\section{Die ontmaskering van die bose}

daar sal geen droefheid, geween en moeite wees nie). Alles wat die stad opeis, word, ironies genoeg en paradoksaal, omgekeer.

Hierdie intense uitsprake omring die oproep tot dubbele vergelding. Al hierdie uitsprake moet verstaan word binne die literêre konteks waarin die uitbuitende lewensstyl van Babilon en die inherente lasterlike aard daarvan bespreek word. 'n Stad wat soveel arrogante en lasterlike aansprake maak en soveel geweld op sy kerfstok het, verdien 'n dubbele oordeel. Kiddle (1940:366-7; my kursivering) het in 'n insiggewende opmerking die gedeelte beskryf as gerig teen

a society so hopelessly depraved that evil is acclaimed as good. Whatever its psychological origin, the exclamation in verse 6 is not the prayer of a Christian that his enemies may be persecuted, but the interpretation made by a Christian of the heavenly response to cruelty, and the wickedness of irreclaimable evil-doers. John is here formulating not the victim's cry against the persecutor, but something like a judicial pronouncement on the sins of civilization, carried to their farthest limits ... and the pronouncement is made by a voice from heaven.

Die sleutel opmerking in Kiddle se aanhaling is dat hierdie dubbele oordeel kom oor 'n stad wat die bose as goed voorhou. Gelowiges tree dus nou as regters op wat die boosheid dubbel en dwars veroordeel en verwerp.

Hierdie hoofstuk sou vir die gehoor soveel meer ironies gewees het omdat hulle leef in 'n omgewing waar hulle as klein groep teenoor 'n magtige ryk te staan gekom het. Maar wat vir hulle na 'n oormag lyk ("Wie is soos die dier, wie kan teen hom oorlog voer", roep die wêreldbewoners uit in Op 13:4), is, vanuit 'n hemelse perspektief, gedoem tot ondergang en vernietiging. Die karakterisering is besonder dig wanneer dit in die lig van die boek as geheel gelees word: vroeër vra die heiliges na vergelding (Op 6:10) en moet hulle wag tot die getal van martelare vol word (Op 6:11). Nou kan hulle die oordeel van God vier. Hulle rou, trane en pyn is verby. Hulle word getransformeer van slagoffers tot oorwinnaars, selfs regters. Die bose is uiteindelik ontmasker en oorwin. Maier (2002:179) skryf

Revelation 12-13 and 17-18 are excellent examples of demystifying, oppositional irony. As we have seen, the question "who is like the beast" (13:4) expresses a dramatic irony arising out of a clever juxtaposition between what the reader knows and what the deceived idolators do not. The audience knows that the beast deceives them with counterfeit signs and wonders because the narrator tells us so (13:13-15), but those guitly of false worship do not know, shut out as they are from the narrative commentary. 


\section{SLOT}

In Openbaring 18 word verskeie vorme en aspekte van geweld uitgebeeld. Geweld is die oorheersende tema van die gedeelte en het ' $n$ duidelike multidimensionele karakters. Die literêre bedrewenheid van die skrywer maak hierdie teks besonder ryk aan betekenis waarin die oorkoepelende geheel, die intra- en intertekstuele lyne en die individuele motiewe op baie maniere dimensies van die teks aanwys en ontsluit.

In die fokus van die vertelling staan die magtige stad Babilon. Reeds die naam wys op die religieuse aard van geweld. Babilon as berugte vyand van God se volk verteenwoordig die bose wat God se skepping afbreek en tot niet maak - bevestig deur die teks se verwysings na die fisieke moord op gelowiges. Geweld kom ook na vore in 'n religieuse sin in die absolute magsvergryping van Babilon in sy lasterlike self-vergoddeliking. Hierdie religieuse geweld word bevestig deur die simbool van die Nuwe Jerusalem wat met Babilon kontrasteer. Dit is die stad van God wat as paradysagtige oord geen plek vir geweld het nie en waarin God verheerlik word. Vir die skrywer van Openbaring is geweld veral afskuwelik weens sy impak op mense se geestelike bestaan. Vir Johannes met sy monoteïstiese, JoodsChristelike agtergrond tas die arrogansie van die stad die verhouding tussen God en mens fundamenteel aan. Die stad se geslote self-beeld het alleen ruimte vir homself en sy gewaande oneindige heerskappy.

Geweld het ook 'n politieke karakter. Die stad en sy konings maak aanspraak op 'n ewige ryk. Maar in hierdie hoofstuk word die politieke dimensie veral met ekonomiese geweld gekombineer. Die ekonomiese geweld is multi-dimensioneel in die kleine: dit is geweld wat 'n hele ryk op sleeptou neem, wat die lewens van groepe van meelopers bepaal en wat die daaglikse leefstyl van mense fundamenteel aantas. In die proses word oor mense getrap en word hulle in 'n absolute magsgreep as besittings toegeëien. Hier gaan dit ook om meer as net 'n bedreiging van gelowiges. Alle inwoners van die aarde is slagoffers van geweld. En ook hier gaan dit nie bloot net om die ekstreme vorm van moord nie. Die geweld deurdring en verontmenslik op 'n omvattende manier die alledaagse lewe. ${ }^{67}$ Die waardigheid van menselewens word tot op die mees basiese vlak van oorlewing, van eet en drink aangetas.

Die teks spel ook die gevolge van geweld uit. Geweld skep in die voorstelling van Babilon geweld. Die gewelddader kry 'n gewelddadige einde, veroorsaak deur sy eie meelopers. Daarmee word die tragedie van geweld uitgebeeld. Dit is ' $n$ verskynsel wat op sigself voed en dus 'n spiraalagtige

\footnotetext{
${ }^{67}$ Vergelyk Openbaring 13:16-17 waar die dier uit die aarde mense met sy naam merk voordat hulle kan koop of verkoop.
} 


\section{Die ontmaskering van die bose}

karakter het. Terwyl die fisieke geweld van Babilon helder na vore kom in die moord op mense, is die gevolge van die geweld vir sommige nie altyd deursigtig nie. Wie gewoond geraak het aan en gebaat het by geweld, soos in die geval van die meelopers, word so afgestomp dat die verlies daaraan tot ontsteltenis kan lei. Terselfdertyd beklemtoon die skrywer ook hoe geweld homself wegsteek. Slegs deur goddelike ingryping kan die gewelddadige karakter van die bose ontmasker word. Juis dit maak geweld so gevaarlik.

Die teks en teksgedeeltes onderstreep by herhaling dat Babilon se gewelddadigheid eintlik en oplaas deur God se regverdige oordeel beëindig word. Dit is 'n oordeel wat vir Johannes so belangrik is dat hy dit met die opening van die sewende seël in Openbaring 11:15-19 al aankondig. Daar aanbid die 24 ouderlinge God met die woorde dat God se kragtige heerskappy begin het. Die wraak van God teen die woedende nasies het aangebreek. Die tyd vir vernietiging van die vernietigers van die aarde het aangebreek. Sedert die opening van die sewende seël hang die swaard van oordeel en vernietiging dus oor hulle wat in woede God se aarde vernietig

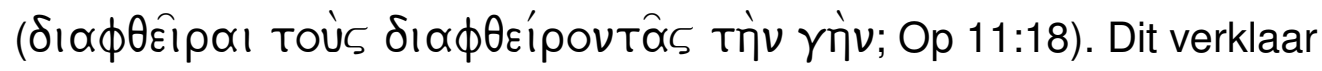
waarom die sewende seël gebreek word terwyl harde stemme in die hemel uitroep: die koninkryk van die aarde het die koninkryk van die Here en sy Messias geword. Die oordeel van God beteken die suiwering van die aarde en sy herstel tot goddelike ryk.

In sy agonistiese konteks praat Johannes in sy ewe agonistiese teks by tye intense oorlogstaal, aangespoor met die hulp van sy heilige tradisies. Sy verontwaardiging oor 'n situasie van onreg, spoor hom aan tot hiperbole, ironieë en paradokse. Hy ontmasker 'n gedugte vyand en spoor sy lesers aan om met absolute toewyding hulle profetiese getuienistaak na te kom. Deur hulle getuienis moet hulle rigterlik dubbel terugslaan. Sy tyd van onreg laat nie ruimte vir broodjies bak nie. Te veel is op die spel. Die welsyn van die wêreld en die leefwêreld van die mensdom word ernstig bedreig. Die goddelike regspraak behels meer net as 'n skuldigbevinding. Dit impliseer daadwerklike verwydering, dubbele vergelding teenoor die wat die ruimte van vrede en menslikheid in die weg staan.

Opvallend is hoedat die geweld van Babilon stuit teen God se groter mag. God trek die grense. Dit is juis op hierdie punt dat Johannes 'n produk van sy tyd word. God se stuit van geweld word self gewelddadig. God verwoes en vernietig. God se volk vergeld dubbel. Die hiperboliese, paradoksale en ironiese taal huiwer nie om harde geweldstaal in te trek in die verset teen Babilon nie. In ireniese kontekste sal sommige Christene vandag anders oor geloof wil praat en ander weer besorgd sal wees oor hoe sommige fanatici die boek sou kon misbruik tot die aansporing van geweld. Die 
uitdaging is om op 'n etiese verantwoorde manier te kan luister na 'n woedende profeet wat met 'n sin van geregtigheid en vanuit sy traumatiese geloofservaring kryf oor 'n tyd waarin hy gevoel het dat boosheid as goddelik voorgehou is. ${ }^{68}$ Heilige woede, hoe oordrewe en oorspits ook al, het dikwels in die geskiedenis van wêreldliteratuur, maar ook in die Bybel die aangrypendste literatuur opgelewer. Dit is in ekstreme omstandighede dikwels die enigste effektiewe manier om die Bose te ontmasker.

\section{Literatuurverwysings}

Aune, D E 2003. s v Irony. The Westminster Dictionary of New Testament and Early Christian Literature and Rhetorics.

Aune, D 1998. Revelation 6-16. Dallas, TX: Word. (Word Biblical Commentary 52.)

Barr, D L 1986. The apocalypse of John as oral enactment. Interpr 40, 245-56.

Barr, D L 1998. Tales of the end: A narrative commentary on the book of Revelation. Santa Rose, CA: Polebridge.

Barr, D L 2003. The story John told: Reading Revelation for its plot, in Barr 2003:1123.

Barr, D L (ed) 2003. Reading the Book of Revelation: A resource for students. Atlanta, GA: Society of Biblical Literature.

Barr, D L (ed) 2006. The reality of the Apocalypse: Rhetoric and politics in the Book of Revelation. Atlanta, GA: Society of Biblical Literature.

Bauckham, R J 1993. The climax of prophecy: Studies on the Book of Revelation. Edinburgh: Clark.

Beale, G K 1999. The Book of Revelation: A commentary on the Greek text. Grand Rapids, MI: Eerdmans. (NIGCT.)

Beasley-Murray, G R 1974. Revelation. Grand Rapids, MI: Eerdmans. (The New Century Bible Commentary.)

Biguzzi, G 2003. A figurative and narrative language grammar of Revelation. NovT 45, 382-402.

Boesak, A A 1987. Comfort and protest: The Apocalypse from a South African perspective. Philadelphia, PA: Westminster.

Boring, M E 1989. Revelation. Louisville, KY: John Knox. (Interpretation.)

Bühlmann, W \& Scherer K 1994. Sprachliche Stilfiguren der Bibel: Von Assonanz bis Zahlenspruch. Ein Nachschlagewerk. Brunne: TVG.

Caird, G B 1966. The Revelation of St John the divine. Edinburgh: Clark. (Black's New Testament Commentaries.)

Callahan, A D 1995. The language of the Apocalypse. HTR 88, 453-70.

Collins, A Y 1979. The Apocalypse. Collegeville, MN: Liturgical Press.

Collins, A Y 1983. Persecution and vengeance in the Book of Revelation, in Hellholm 1983:728-49.

Collins, A Y 1984. Crisis and catharsis: The power of the Apocalypse. Philadelphia, PA: Westminster.

\footnotetext{
${ }^{68}$ Die hermeneutiese konsekwensies van Openbaring 18 sal ek elders bespreek. Hier is slegs ruimte vir 'n deskriptiewe beskrywing en eksegetiese analise van die teks.
} 


\section{Die ontmaskering van die bose}

Connors, R J 1997. Composition-Rhetoric: Backgrounds, theory and pedagogy. Pittsburg, CA: University of Pittsburgh Press.

Desrosiers, G 2000. An introduction to Revelation: A pathway to interpretation. London: Continuum. (CBSS.)

De Villiers, P G R 1988. The Lord was crucified in Sodom and Egypt: Symbols in the Apocalypse of John. Neotest 22, 125-138.

De Villiers, P G R 2000. Prime evil and its many faces in the Book of Revelation. Neotest 34, 57-86.

De Villiers, P G R 2002a. Persecution in the Book of Revelation. Acta Theologica 22, 47-70.

De Villiers, P G R 2002b. Rome in the historical interpretation of Revelation. Acta Patristica et Byzantina 13, 120-42.

De Villiers, P G R 2002c. The composition of Revelation 17 and its place in the Book as a Whole. Acta Patristica et Byzantina 13, 97-119.

De Villiers, P G R 2004a. The role of composition in the interpretation of the rider on the white horse and the seven seals in Revelation. HTS 60, 125-153.

De Villiers, P G R 2004b. The composition of Revelation 14:1-15:8. Pastiche or perfect pattern? Neotest 38, 209-49.

De Villiers, P G R 2004c. The septets of seals and angels in Revelation: A missing Link? Acta Patristica et Byzantina 15, 119-143.

De Villiers, P G R 2004d. The sixth seal in Revelation 6:12-17. Acta Theologica Supplementum 6, 1-30.

De Villiers, P G R 2007. History, mysticism and ethics in Oecumenius: A hermeneutical perspective on the earliest extant Greek commentary on Revelation. SHE 33, 315-36.

De Villiers, P G R 2007a. Divine and human love in the Revelation of John. Acta Patristica et Byzantina 18, 43-59.

Fekkes, J 1994. Isaiah and prophetic traditions in the Book of Revelation: Visionary antecedents and their development. Sheffield: JSOT. (JSNTSSS 93.)

Friesen, S 2006. Sarcasm in Revelation 2-3: Churches, Christians, true Jews, and satanic synagogues, in Barr 2006:127-44.

Garrow, A J P 1997. Revelation. London: Routledge. (New Testament Readings.)

Giblin, C H 1991. The Book of Revelation: The Op book of prophecy. Collegeville, MN: Liturgical. (Good News Studies 34.)

Giesen, H 1997. Die Offenbarung des Johannes. Regensburg: Pustet.

(Regensburger Neues Testament.)

Hawhee, D 2002. Agonism and arete. Philosophy and rhetoric 35, 185-207.

Hellholm, D 1989. Apocalypticism in the Mediterranean world and the Near East. Tübingen: Mohr.

Johnson, A F 1996. Revelation. Grand Rapids, MI: Zondervan.

Kiddle, M 1946. The Revelation of St John. London: Hodder \& Stoughton.

Knight, J 1999. Revelation. Sheffield: Sheffield Academic Press. (Readings. A New Biblical Commentary.)

Kraft, H 1974. Die Offenbarung des Johannes. Tübingen: Mohr.

Ladd, G E 1972. A commentary on the Revelation of John. Grand Rapids, MI: Eerdmans.

Leung, S 2002. Conflict talk: A discourse analytical perspective. Journals.tclibrary.org/index.php/tesol/article/viewArticle/20 
Lohmeyer, E 1953. Die Offenbarung des Johannes. Tübingen: Mohr. (HNT 16.)

Maier, H O 2002. Apocalypse recalled: The Book of Revelation after Christendom. Minneapolis, MN: Fortress.

Maier, $\mathrm{H} O$ 2005. Coming out of Babylon: A first-world reading of Revelation among immigrants, in Rhoads 2005:62-81.

Marshall, J W 2001. Parables of war: Reading John's Jewish Apocalypse. Waterloo: Wilfrid Laurier University Press.

Marshall, J W 2005. Collatoral damage: Jesus and Jezebel in the Jewish War, in Matthews \& Gibson 2005:35-50.

Matthews, S \& Gibson, E L (eds), Violence in the New Testament. New York, London: Clark.

Michaels, J R 1997 Revelation. Downers Grove, IL: InterVarsity. (IVP New Testament Commentary Series.)

Millard, A 2000. Reading and writing in the time of Jesus. Sheffield: Sheffield Academic.

Mounce, R H 1977. The Book of Revelation. Grand Rapids, MI: Eerdmans. (NICC.)

Müller, U B 1995. Offenbarung. Wien: Herder.

Mussies, G 1971. The morphology of Koine Greek as used in the Apocalypse of St John: A study in bilingualism. Leiden: Brill.

Okoye, J C 2005. Power and worship: Revelation in an African perspective, in Rhoads 2005:110-26.

Ong, W J 1981. Fighting for life: Contest, sexuality, and consciousness. Ithaca, NY: Cornell University Press.

Osborne, G R 2002. Revelation. Grand Rapids, MI: Baker Academic. (BECNT.)

Pippin, T 1995. Death and desire: The rhetoric of gender in the Apocalypse of John. Louisville, KY: Westminster John Knox.

Pippin, T 2005. The heroine and the whore: The Apocalypse of John in feminist perspective, in Rhoads 2005:127-45.

Prigent, P 2001. Commentary on the Apocalypse of St John. Tübingen: Mohr Siebeck.

Rees-Miller, J 2000. Power, severity and context in disagreement. Journal of Pragmatics 32, 1087-1111.

Resseguie, J L 1998. Revelation unsealed: A narrative critical approach to John's Apocalypse. Leiden: Brill. (Biblical Interpretation Series.)

Rhoads, D 2005. From every people and nation: The Book of Revelation in intercultural perspective. Minneapolis, MN: Fortress.

Richard, P 2005. Reading the Apocalypse: Resistance, hope and liberation in Central America, in Rhoads 2005:146-64.

Roloff, J 1987. Die Offenbarung des Johannes. Zürich: Theologischer Verlag. (Zürcher Bibelkommentare 18.)

Royalty, R M 1998. The streets of heaven: The ideology of wealth in the Apocalypse of John. Macon, GA: Mercer University Press.

Schussler-Fiorenza, E 1968. The eschatology and composition of the Apocalypse. $C B Q 30,537-569$.

Schüssler-Fiorenza, E 1981. Invitation to the Book of Revelation. New York:

Doubleday.

Schüssler-Fiorenza, E 1998. The Book of Revelation. Minneapolis, MN: Fortress. 


\section{Die ontmaskering van die bose}

Soeting, A G 2001. Auditieve aspecten van het Boek Openbaring van Johannes. Zoetermeer: Boekencentrum.

Swete, H B 1911. The Apocalypse of St John: The Greek text with introduction, notes and indices. London: MacMillan.

Tannen, D 2002. Agonism in academic discourse. Journal of Pragmatics 34, 16511669.

Taylor, A W 2006. Glass houses: Surrey, Petrarch, and the religious poetics of the "London" invective, in The review of English studies 57, 433-55.

Thompson, L L 1990. The Book of Revelation: Apocalypse and Empire. New York: Oxford University Press.

Van der Waal, C 1971. Openbaring van Jezus Christus: Inleiding en vertaling. Groningen: De Vuurbaak.

Van Hartingsveld, L 1985. Revelation. Grand Rapids, MI: Eerdmans.

Van Schaik, A P 1971. De Openbaring van Johannes. Roermond: Romen.

Visser, A J 1972. De Openbaring van Johannes. PNT. Nijkerk: Callenbach.

\section{TEKSANALISE VAN OPENBARING 18}

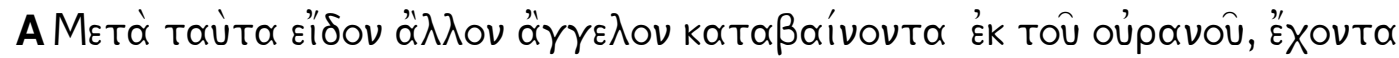

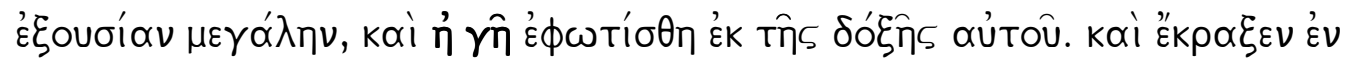

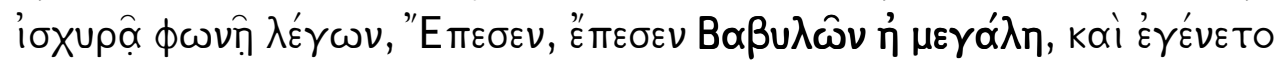

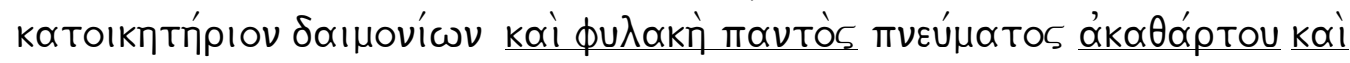

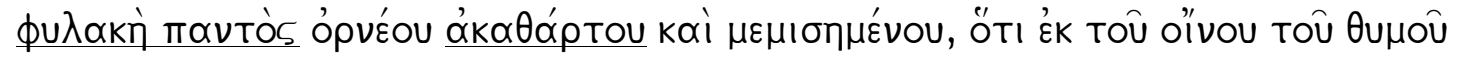

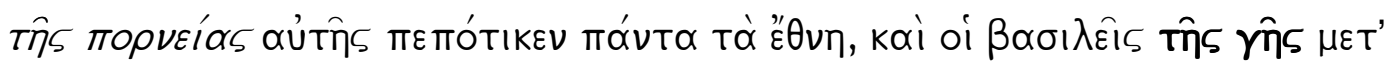

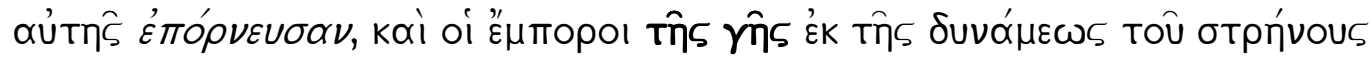

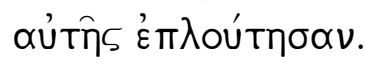

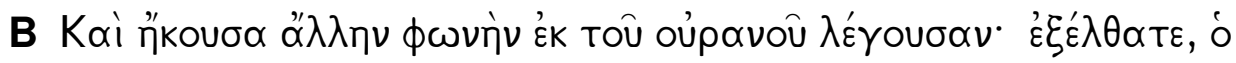

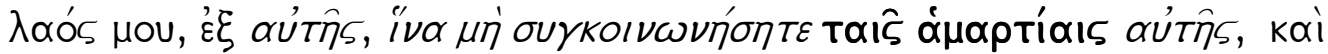

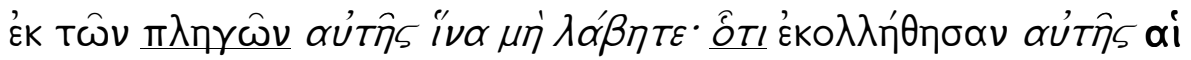

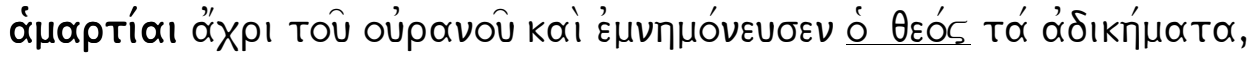

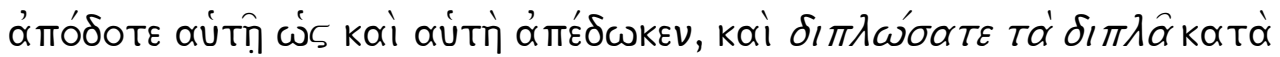

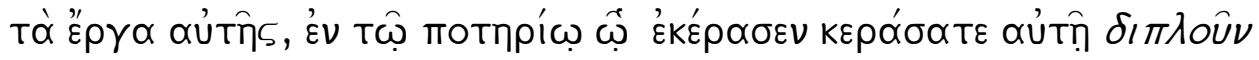

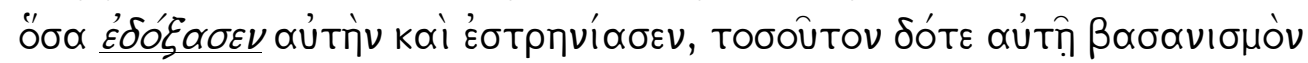

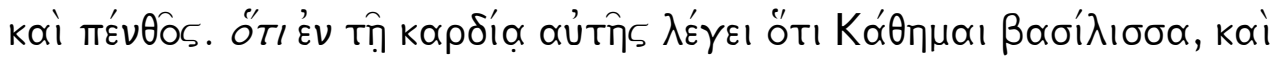

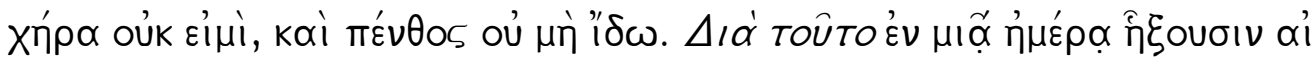

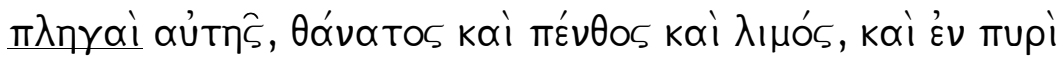

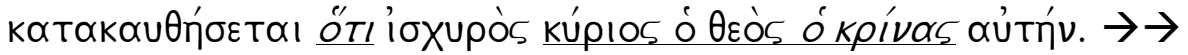

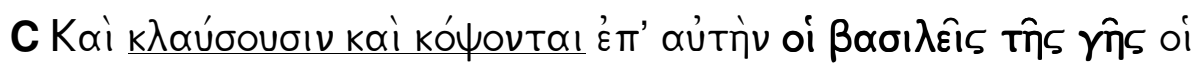

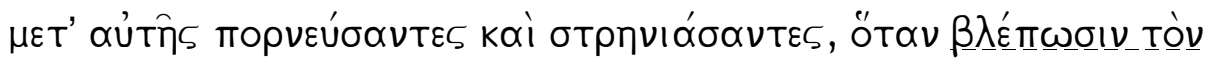
Ka

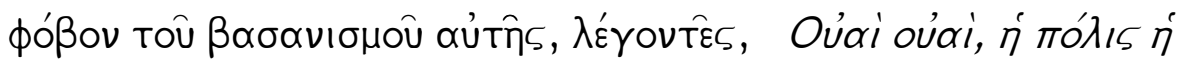

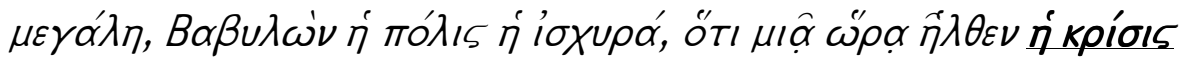
oOU. 


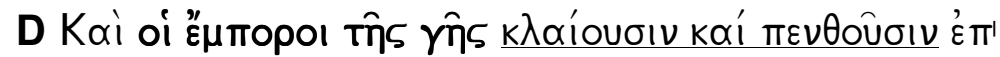

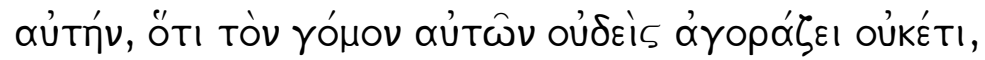

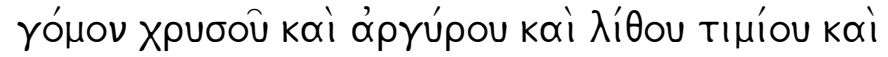

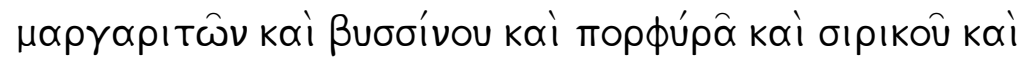

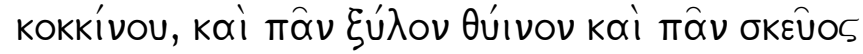

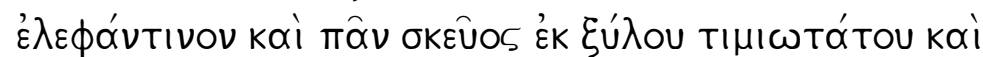

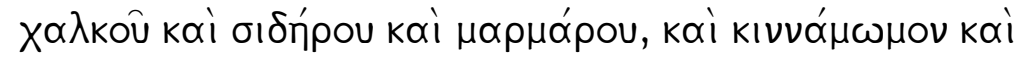

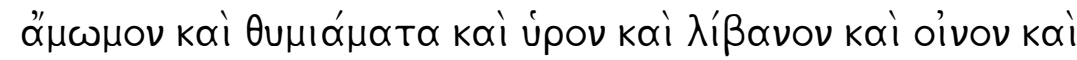

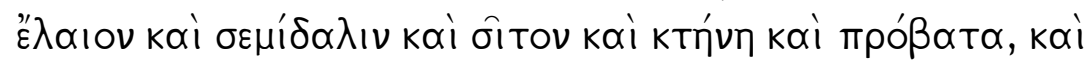

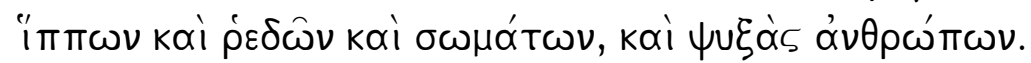

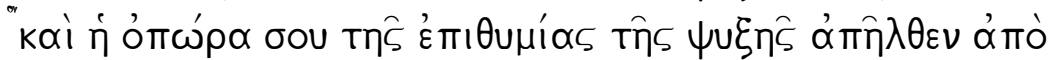

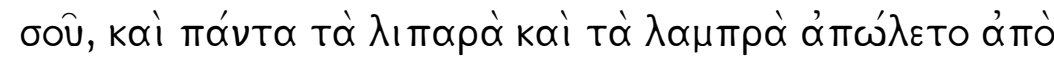

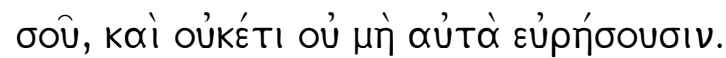

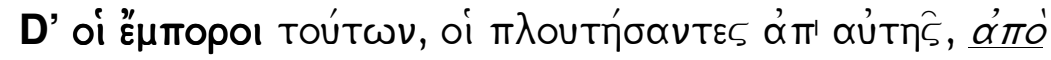

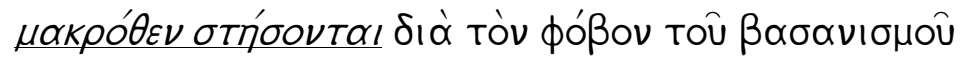

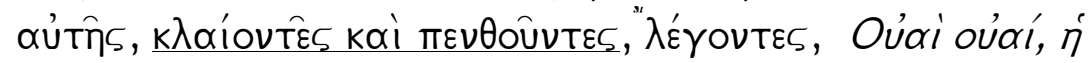

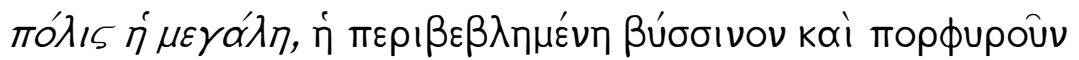

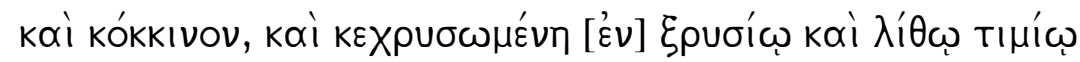

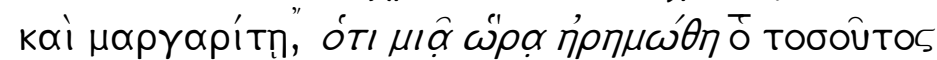
$\pi$ त०ôtos.

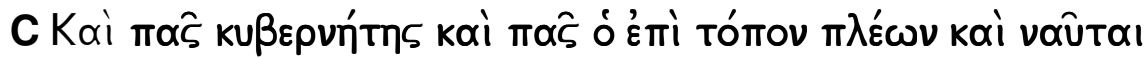

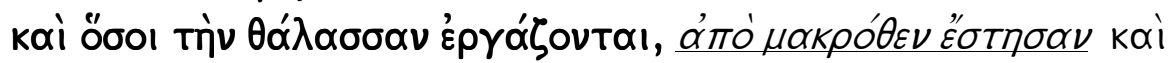

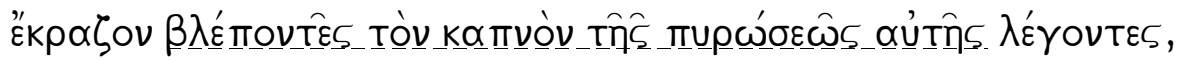

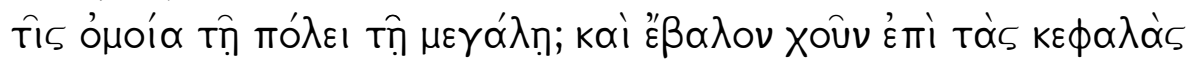

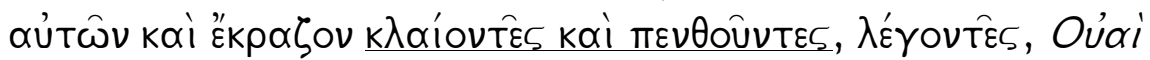

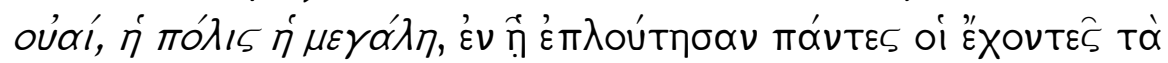

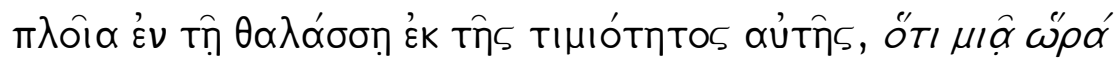
$\eta \dot{\eta} \cap \mu \omega \dot{\theta} \theta$.

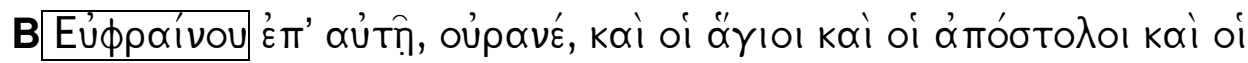

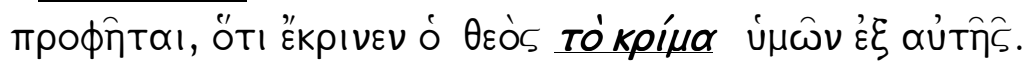

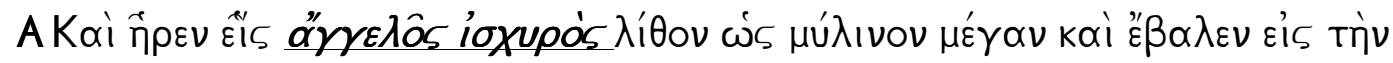

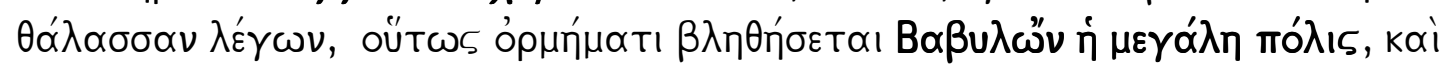

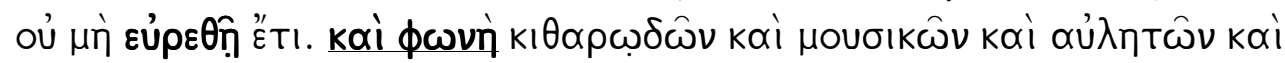

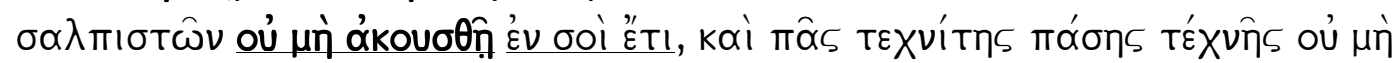

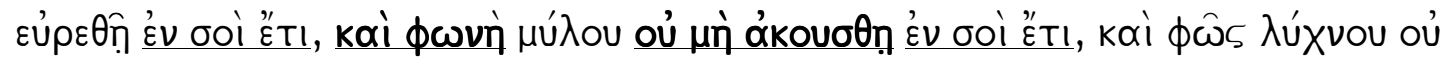

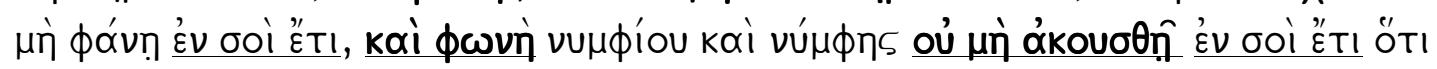

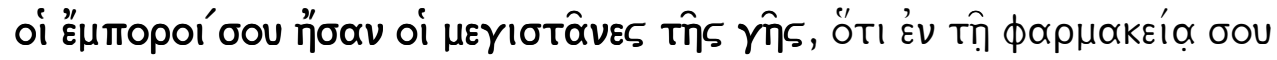

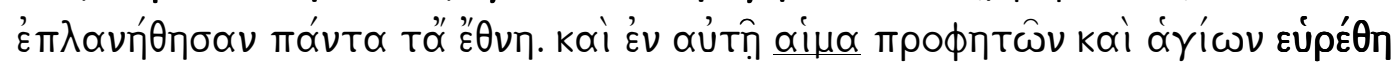

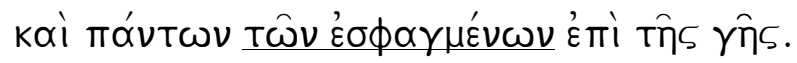

